Article

\title{
Survivability of Soil and Permafrost Microbial Communities after Irradiation with Accelerated Electrons under Simulated Martian and Open Space Conditions
}

\author{
Vladimir Cheptsov 1,2,*iD, Elena Vorobyova 1,2, Andrey Belov ${ }^{1}$, Anatoly Pavlov ${ }^{3}$, \\ Denis Tsurkov $^{3}$, Vladimir Lomasov ${ }^{4}$ and Sergey Bulat ${ }^{5,6}$ iD \\ 1 Department of Soil Biology, Lomonosov Moscow State University, Moscow 119991, Russia; \\ esautin@yandex.ru (E.V.); a.a.belov@ecostudy.org (A.B.) \\ 2 Space Research Institute, Russian Academy of Sciences, Moscow 117997, Russia \\ 3 Ioffe Physical-Technical Institute, Russian Academy of Sciences, St. Petersburg 194021, Russia; \\ anatoli.pavlov@mail.ioffe.ru (A.P.); d.tsurkov@me.com (D.T.) \\ 4 Peter the Great St. Petersburg State Polytechnic University, St. Petersburg 194021, Russia; \\ lomasoff@yandex.ru \\ 5 Petersburg Nuclear Physics Institute Named by B.P. Konstantinov of National Research Centre \\ "Kurchatov Institute", Gatchina 188300, Russia; bulat@omrb.pnpi.spb.ru \\ 6 Institute of Physics and Technology, Ural Federal University, Ekaterinburg 620002, Russia \\ * Correspondence: cheptcov.vladimir@gmail.com; Tel.: +7-929-917-07-80
}

Received: 1 July 2018; Accepted: 6 August 2018; Published: 8 August 2018

\begin{abstract}
One of the prior current astrobiological tasks is revealing the limits of microbial resistance to extraterrestrial conditions. Much attention is paid to ionizing radiation, since it can prevent the preservation and spread of life outside the Earth. The aim of this research was to study the impact of accelerated electrons $(\sim 1 \mathrm{MeV})$ as component of space radiation on microbial communities in their natural habitat - the arid soil and ancient permafrost, and also on the pure bacterial cultures that were isolated from these ecotopes. The irradiation was carried out at low pressure ( $\sim 0.01$ Torr $)$ and low temperature $\left(-130^{\circ} \mathrm{C}\right)$ to simulate the conditions of Mars or outer space. High doses of $10 \mathrm{kGy}$ and $100 \mathrm{kGy}$ were used to assess the effect of dose accumulation in inactive and hypometabolic cells, depending on environmental conditions under long-term irradiation estimated on a geological time scale. It was shown that irradiation with accelerated electrons in the applied doses did not sterilize native samples from Earth extreme habitats. The data obtained suggests that viable Earth-like microorganisms can be preserved in the anabiotic state for at least 1.3 and 20 million years in the regolith of modern Mars in the shallow subsurface layer and at a $5 \mathrm{~m}$ depth, respectively. In addition, the results of the study indicate the possibility of maintaining terrestrial like life in the ice of Europa at a $10 \mathrm{~cm}$ depth for at least $\sim 170$ years or for at least 400 thousand years in open space within meteorites. It is established that bacteria in natural habitat has a much higher resistance to in situ irradiation with accelerated electrons when compared to their stability in pure isolated cultures. Thanks to the protective properties of the heterophase environment and the interaction between microbial populations even radiosensitive microorganisms as members of the native microbial communities are able to withstand very high doses of ionizing radiation.
\end{abstract}

Keywords: astrobiology; Mars; accelerated electrons; gamma radiation; microbial communities; radioresistance; native environment; soil; permafrost 


\section{Introduction}

According to current knowledge, life on Earth exists within a limited range of the balanced impacts of physical and chemical factors. Significant changes in the amplitude of the impact can lead to the disturbances of biosystems up to the disappearance of life. Despite the long-standing scientific interest in the problem of living cell resistance to adverse impacts, and numerous biological studies of extreme habitats, the question of the limits of cell viability in native environment under stress conditions remains open, and in recent decades has acquired the scale of an astrobiological problem. The viability of microorganisms under the influence of extraterrestrial cosmic factors is one of the priority issues of modern astrobiological studies [1-3]. Much attention is paid to ionizing radiation being considered as one of the main factors that can prevent the preservation and spread of life outside the Earth [4-10]. Indeed, among physicochemical factors that change the natural habitat and, above all, organisms per se, ionizing radiation is undoubtedly of prior importance having a direct effect on the genetic material of a living cell.

The influence of ionizing radiation in relatively low doses on different organisms has been studied for a long time, and radiobiology generalizes and continues to accumulate experience of such studies [11-13]. Nevertheless, to plan and conduct astrobiological planetary studies, it is necessary to evaluate the effect of high doses of various components of cosmic radiation on microorganisms adapted to a native habitat [6-10]. In addition, the tasks of astrobiology require a differentiated approach to astrobiological models (Mars, ice satellites, Titan, etc.), taking into account hypothetical models of biospheres, as well as radiation fluxes and other data about the planet that characterize the environment.

It has been proved that the conditions under which irradiation occurs (temperature, pressure, etc.) substantially correct radiation effects $[5-7,10]$. Microorganisms in natural heterophase mineral media (soils, sediments) are well protected against the stressful effects of physical and chemical factors. A lot of data there is published already on the increased resistance to stress of microorganisms in biofilms or microbial communities in situ in native habitat in comparison with pure microbial cultures [6,14-18]. Therefore, in order to correctly assess the radioresistance of terrestrial microorganisms in the extraterrestrial regolith or other habitat, the closest possible reproduction of the relevant physicochemical factors is necessary, while preserving the natural environmental model, to which microbial communities are adapted.

Recent studies have shown that the resistance of microorganisms to gamma radiation is significantly underestimated [6-9,19]. Gamma radiation is a small part of cosmic radiation $[5,10]$. Different types of ionizing radiation differ in their biological effects [5]. For astrobiological modeling it is necessary to study in situ the stability of natural communities of microorganisms to various types of cosmic radiation in conditions that are as close as possible to extraterrestrial models. Elucidation of limiting doses and the identification of the most resistant in situ microorganisms or their communities will enable not only to correct the search tasks, but, despite the conventionality of extrapolating calculations to real conditions, it will allow for estimating the expediency of searching for life on a particular space object.

The aim of this research was to study the effect of accelerated electrons as a component of cosmic radiation at high doses of $10 \mathrm{kGy}$ and $100 \mathrm{kGy}$ on microbial communities in their natural habitat-arid soil and ancient permafrost, as well as on pure bacterial cultures that were isolated from these biotopes. Irradiation was carried out under low pressure $(\sim 0.01$ Torr $)$ and low temperature $\left(-130^{\circ} \mathrm{C}\right)$ conditions, to simulate Martian and outer space environments. When considering the usage of different units of ionizing radiation dose in radiobiological literature we would clarify that gray (Gy) is defined as the absorption of one joule of radiation energy per kilogram of matter, and Gy is equal to $100 \mathrm{rad}$.

A study of the effect of elevated radiation doses, which significantly exceed the amplitude fluctuations of the radiation on the surface of Mars [20-23], is necessary for the extrapolation of biological effects on the geological time scale. Laboratory experiments do not allow for studying the long accumulation of doses of relatively low intensity in the microbial biomass of natural soil. The 
main question of the present study is how long the biosphere of Mars could be maintained after the supposed catastrophic change in planetary conditions [24-29], the gradual loss of the atmosphere [30], and the formation of a modern climate.

\section{Materials and Methods}

\subsection{Objects of Study}

An arid soil sample (SN2) from the Negev desert and the ancient Arctic permafrost sample (M-1/91) were used as objects in the experiments, as well as pure cultures of bacteria Arthrobacter polychromogenes SN_T61 and Kocuria rosea SN_T60. The Arctic permafrost sample (M-1/91) was taken from the 1/91 well located in the Lower Kolyma Lowland (Yakutia) between the Bolshaya Chukochya and Malaya Konkovaja rivers in the sublatitudinal oler uplift [31]. The sample was taken at a depth of $34.0 \mathrm{~m}$, from the ancient layers of the Oler suite, which did not melt for 1.8-2 million years. The temperature in the well was $-7 \ldots-12^{\circ} \mathrm{C}$. Sampling and transportation methods and conditions were described earlier [32]. This sample was used earlier in our model experiments, with high doses of gamma irradiation at low temperature and low pressure [6,33].

The arid soil sample (SN2) was taken from the Negev desert in the Avdat $\left(30^{\circ} 47^{\prime} \mathrm{N} / 34^{\circ} 46^{\prime} \mathrm{E}\right)$ at a depth of 5-10 $\mathrm{cm}$ (horizon A) [34]. This area receives about $100 \mathrm{~mm}$ of precipitation during the whole year with months from June to October being the dry season with no precipitation at all. Soil-forming rocks are loess like loams. According to the WRB soil classification system, the soil is classified as Aridic Calcisols [35]. This sample was also used earlier in our model experiments with gamma irradiation at low temperature and low pressure [33].

The chemical characteristics of the samples are shown in Table 1. Ion concentrations in aqueous extracts from the samples were determined using Dionex ICS-1100 Ion Chromatography System (Dionex Corporation, Sunnyvale, CA, USA), according to manufacturer recommendations; total organic carbon content was determined using the method of oxidation in potassium dichromate [36].

Table 1. Chemical characteristics of the samples studied.

\begin{tabular}{ccc}
\hline \multicolumn{1}{c}{ Sample } & SN2 & M-1/91 \\
Attribute & & 7.51 \\
$\mathrm{pH}$ & 8.11 & Traces \\
$\mathrm{NO}^{2-}, \mathrm{mg} / \mathrm{kg}$ & Traces & 0.89 \\
$\mathrm{NO}^{3-}, \mathrm{mg} / \mathrm{kg}$ & 1.03 & 3.34 \\
$\mathrm{NH}_{4}{ }^{+}, \mathrm{mg} / \mathrm{kg}$ & 4.12 & 49.84 \\
$\mathrm{Cl}^{-}, \mathrm{mg} / \mathrm{kg}$ & 58.15 & 129.29 \\
$\mathrm{CO}_{3}^{2-}, \mathrm{mg} / \mathrm{kg}$ & 330.41 & 87.57 \\
$\mathrm{Na}^{+}, \mathrm{mg} / \mathrm{kg}$ & 512.7 & 3.23 \\
$\mathrm{Mn}^{2+}, \mathrm{mg} / \mathrm{kg}$ & 1348.2 & 170.4 \\
$\mathrm{Mg}^{2+}, \mathrm{mg} / \mathrm{kg}$ & 136.46 & 40.47 \\
$\mathrm{~K}^{+}, \mathrm{mg} / \mathrm{kg}$ & 877.5 & 29.55 \\
$\mathrm{Fe}^{2+}+\mathrm{Fe}^{3+}, \mathrm{mg} / \mathrm{kg}$ & 4.35 & 0.32 \\
Total organic carbon, \% & 1.27 & \\
\hline
\end{tabular}

Bacterial strains Arthrobacter polychromogenes SN_T61 and Kocuria rosea SN_T60 were isolated previously from a sample of arid soil (sample SN), taken at the same location as the sample SN2. Sample SN and bacterial strains Arthrobacter polychromogenes SN_T61 and Kocuria rosea SN_T60 were described in our previous papers [33,37-39]. It was shown that these strains are able to withstand gamma irradiation up to $10 \mathrm{kGy}$ doses at low pressure $(1$ Torr $)$ and low temperature $\left(-50{ }^{\circ} \mathrm{C}\right)$ conditions, without a significant reduction in the number of living cells [38,39]. The strains are deposited to the Astrobiological Collection of bacteria of Lomonosov Moscow State University (the "Noah's Ark" project, http://depo.msu.ru). 


\subsection{Preparation of Samples for Irradiation with Accelerated Electrons}

Samples of arid soil SN2 (with $\sim 40 \mathrm{~g}$ weight) and permafrost M-1/91 (with $\sim 20 \mathrm{~g}$ weight) were incubated in a thermostat at $+28^{\circ} \mathrm{C}$ for 10 days before irradiation to activate microbial communities in situ and establish homeostasis in order to exclude the consequences of samples storage. Prior to incubation, the arid soil was moistened with sterile distilled water (up to $25 \%$ moisture by weight). Humidification of the permafrost sample M-1/91 was due to the melting of the ice contained in it. No nutrients were added. The samples were then incubated in tightly closed sterile polypropylene containers. After incubation, the samples were dried to an air-dry state at the same temperature for three days to prepare for the irradiation experiment under vacuum conditions.

The biomass of bacteria Arthrobacter polychromogenes SN_T61 and Kocuria rosea SN_T60 in a stationary growth phase was suspended in sterile distilled water and the suspension was introduced into a sterile (heated at $600{ }^{\circ} \mathrm{C}$ for three hours) montmorillonite to immobilize the cells on the mineral matrix, simulating soil conditions. The samples were then thoroughly mixed with a sterile glass rod and dried for three days at $+28^{\circ} \mathrm{C}$.

All of the objects under study were sieved through a sterile sieve with a hole diameter of $0.25 \mathrm{~mm}$, then packed in sterile polyethylene bags ( $20 \mathrm{~mm}$ in diameter). Each bag contained no more than $150 \mathrm{mg}$ with the thickness of the sample layer being $<1 \mathrm{~mm}$. The bags were then hermetically sealed. To control possible contamination of the samples at all stages of the study, a control sample of sterile montmorillonite heated at $600{ }^{\circ} \mathrm{C}$ for three hours was prepared in the same way. Subsequently, this sample was transported, irradiated, stored, and analyzed together with the other samples.

\subsection{Description of the Climatic Chamber}

A climatic chamber was designed for the experiment (Figure 1). The chamber is a cylindrical tank with a "window" of aluminium foil (9) $100 \mu \mathrm{m}$ thick on top. There are cylindrical cups that were installed inside the chamber (4) to reduce the pressure on the foil, and the samples were placed inside them and between them. The rubber ring (3) and a rigid metal ring tightens with 12 bolts (7) were used to seal the "window" of the foil. Under the bottom of the sample chamber there is a liquid nitrogen tank. To improve the thermal conductivity, rods (8) are welded to the bottom of the chamber. Taps (2) are used for pouring liquid nitrogen in. The chamber is pumped by a turbomolecular pump through a tap (6). Inside the chamber there is a thermocouple (5) for temperature control. The chamber together with the liquid nitrogen tank is thermally insulated with a syntepon bounded by an isilone cylinder (1). The chamber can maintain a pressure of $\sim 0.01$ Torr and a temperature of about $-130{ }^{\circ} \mathrm{C}$.
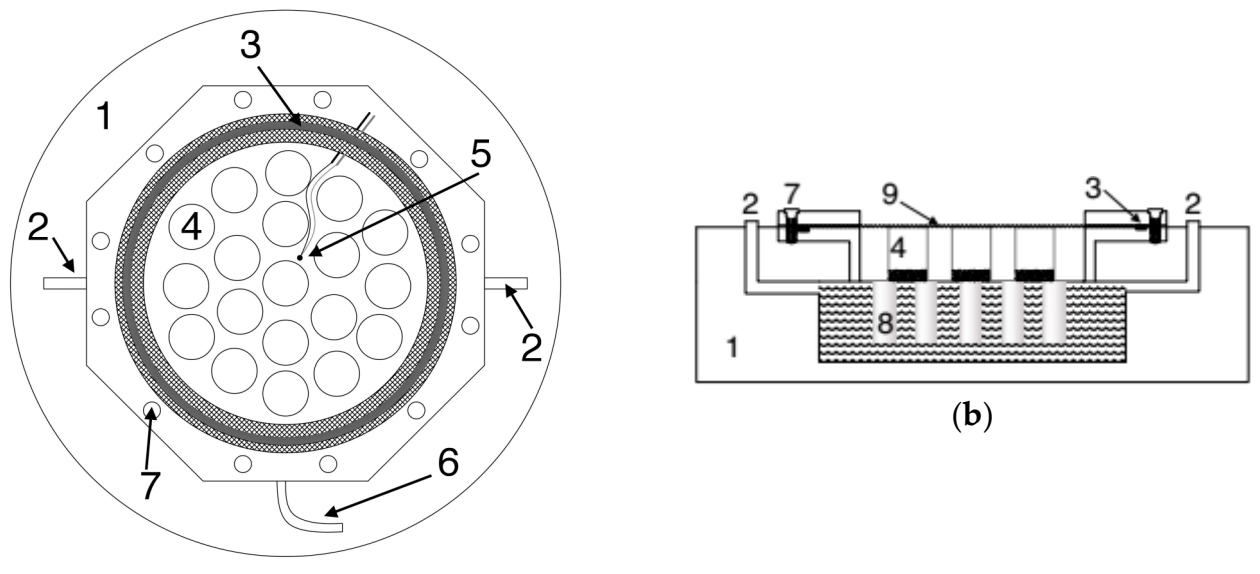

(b)

(a)

Figure 1. Scheme of the climatic chamber: (a) Top view; (b) Side view. 1-Sintepon with isilon cylinder, 2-Tap for filling with liquid nitrogen, 3-Rubber ring, 4-Cylindrical cup, 5-Thermocouple, 6-Tap for air pumping out, 7-Bolt, 8-Rod, and 9-Foil. 


\subsection{Irradiation of Samples with Accelerated Electrons}

Samples in sealed polyethylene bags were placed in a pre-cooled to $-100{ }^{\circ} \mathrm{C}$ irradiation chamber. The bags were then pierced quickly with a sterile steel needle to provide a balanced reduced pressure when exposed, and after that the chamber was immediately sealed and air was pumped out. The temperature during the irradiation was $-130{ }^{\circ} \mathrm{C}$ with pressure being $\sim 0.01$ Torr. The irradiation was carried out using RTE-1B electron accelerator (USSR) with electron energy of $\sim 1 \mathrm{MeV}$. Arid soil samples were irradiated with $10 \mathrm{kGy}$ and $100 \mathrm{kGy}$ doses, permafrost samples were irradiated with $100 \mathrm{kGy}$ dose. The radiation intensity was $0.28 \mathrm{kGy} / \mathrm{s}$ and $2.8 \mathrm{kGy} / \mathrm{s}$ for $10 \mathrm{kGy}$ and $100 \mathrm{kGy}$ doses, respectively, and the duration of irradiation was $\sim 36 \mathrm{~s}$ for both doses. The time from placing the samples in the chamber to unloading from the chamber (including the time of air pumping out, the onset of temperature equilibrium, the exit of personnel from the room, the starting and stopping of the accelerator, and the irradiation) was about $10 \mathrm{~min}$. After irradiation the samples (in polyethylene bags) were unloaded into sterile polypropylene tubes, which were immediately placed in a cooled sterile thermos bottle. Samples were transported at a negative temperature (in thermos with cooling), and then stored at $-18^{\circ} \mathrm{C}$.

In addition, control of low temperature and low pressure impact on the microorganisms was performed. The arid soil samples were placed in the chamber for $10 \mathrm{~min}$ at the same pressure and temperature as during irradiation. The absence of such control for permafrost, as well as permafrost irradiation with only one dose $(100 \mathrm{kGy})$ was due to a small amount of available samples and the inaccessibility of similar ancient permafrost.

In the same way, pure bacterial cultures Arthrobacter polychromogenes SN_T61 and Kocuria rosea SN_T60 immobilized in montmorillonite were irradiated with $10 \mathrm{kGy}$ and $100 \mathrm{kGy}$ doses. Control of low temperature and low pressure impact on the pure bacterial cultures was also performed.

\subsection{Culturing of Microbial Communities}

Determination of the number of culturable heterotrophic bacteria in the soil and permafrost samples was carried out by plating on glucose-peptone-yeast agar (GPY) (peptone-2 g/L, glucose-1 g/L, yeast extract-1 g/L, casein hydrolyzate-1 g/L, CaCO3-1 g/L, and agar-agar-20 g/L) [6]. Prior to inoculation, the microorganisms were desorbed from the mineral particles while using vortex Heidolph Multi Reax for $30 \mathrm{~min}$ at $2000 \mathrm{rpm}$. Suspensions of samples in different dilutions were plated in triplicate with simultaneous control of the nutrient medium sterility, sterility of the water used for dilutions preparing, and control of the presence of foreign air microflora. The plates were incubated at a temperature of $+28^{\circ} \mathrm{C}$ for two weeks.

\subsection{Accounting for the Total Numbers of Prokaryotes}

The total numbers of prokaryotic cells in the samples were determined using epifluorescence microscopy (EFM) with acridine orange dye. The cells were desorbed using ultrasound $(22 \mathrm{kHz}$, 0.4 A, $2 \mathrm{~min}$ ). The preparations for microscopy were made in six replicates and were fixed by heating, then stained, and viewed with a Biomed-6 PR LUM (Russia) microscope with $\times 700$ magnification for 20 fields of view for each replication. Cells with a green fluorescence were counted. The water used for the dilution preparation was simultaneously examined as control. The numbers of prokaryotic cells in samples was calculated by the equation $N=\left(S_{1} \times a \times n\right) /\left(V \times S_{2} \times c\right)$, where $N$ is the number of cells per gram of soil; $S_{1}$ is the square of the preparation $\left(\mu \mathrm{m}^{2}\right) ; a$ is number of cells in the field of view; $n$ is the dilution index; $V$ is the volume of the drop applied $(\mathrm{mL}) ; S_{2}$ is the field of view of the microscope $\left(\mu \mathrm{m}^{2}\right)$; and, $c$ is the sample aliquot weight $(\mathrm{g})$. 


\subsection{Multisubstrate Testing of Integral Metabolic Activity and Functional Diversity of Microbial Communities (MST)}

Potential metabolic activity and the functional diversity of microbial communities have been investigated by the multisubstrate testing method [40-43]. Soil aliquots with $0.3 \mathrm{~g}$ weight were placed in $50 \mathrm{~mL}$ centrifuge cups, diluted with distilled water (1:100), and cells were desorbed using ultrasound ( $22 \mathrm{kHz}, 0.4 \mathrm{~A}, 2 \mathrm{~min})$. Mineral particles were then precipitated by centrifugation ( $2000 \mathrm{rpm}$, $2 \mathrm{~min}$ ). A $2 \mathrm{~mL}$ of saturated solution of the substrate consumption indicator (dehydrogenase activity indicator triphenyltetrazolium bromide) was added to the $20 \mathrm{~mL}$ of supernatant, mixed, and inoculated $200 \mu \mathrm{L}$ of the suspension into each well of a 96-well immunoassay plate containing a set of 47 test substrates [6,9] and mineral salts (the mineral base of the Czapek medium) [44]. The plates were incubated in a thermostat at $+28{ }^{\circ} \mathrm{C}$ for $72 \mathrm{~h}$. The water that was used for the dilution preparation was simultaneously examined as control. The optical density of the solutions in the wells was then photometrically measured at $510 \mathrm{~nm}$ wavelength, and the coefficients of functional biodiversity of the microbial community studied, which are characteristic features of its condition, were calculated using the Eco-Log software $[45,46]$. The analysis was performed in two replicates.

\subsection{Identification of Bacterial Isolates}

Pure bacterial cultures isolated from arid soil and permafrost samples were identified by sequencing of the $16 \mathrm{~S}$ rRNA genes. Polymerase chain reaction (PCR) was performed with primers 63F+1387R [47], 27F+Un1492R [48,49], and 27F+537R [48,50] (Table A1 in Appendix A). The PCR products that were obtained were purified and sequenced by the Research and Production Company "Synthol" (Moscow, Russia) using primers 1100R and 537R [50] (Table A1). Editing of the nucleotide sequences was carried out using the Chromas Lite 2.01 program (http:/ / www.technelysium.com.au). For alignment, comparison, and identification of nucleotide sequences, the Clustal Omega program (http://www.ebi.ac.uk/Tools/msa/clustalo/) and the BLAST algorithm of the GenBank database (http://blast.ncbi.nlm.nih.gov/Blast.cgi) were applied. The isolated strains were deposited in the Astrobiological Collection of bacteria of Lomonosov Moscow State University (http://depo. msu.ru) under the strain numbers KBP.AS.297-KBP.AS.303, KBP.AS.317, KBP.AS.319-KBP.AS.326, KBP.AS.340-KBP.AS.347, and KBP.AS.531-KBP.AS.537. The obtained nucleotide sequences were deposited in GenBank under the accession numbers MH050938-MH050968.

\subsection{Investigation of the Physiological Characteristics of Isolates}

The physiological properties of the isolated strains were studied by inoculation into 96-well immunoassay plates with liquid GPY medium supplemented with triphenyltetrazolium chloride as an indicator of metabolic activity. Phosphate ( $\mathrm{pH} 2-6)$ and carbonate $(\mathrm{pH} 7-12)$ buffer systems were used to determine the range of $\mathrm{pH}$ values that are suitable for growth [51]. Resistance to salts presence was analyzed using liquid GPY nutrient media with the addition of $\mathrm{NaCl}, \mathrm{KCl}, \mathrm{MgSO}_{4}$, or $\mathrm{NaHCO}_{3}$ at concentrations of $2,5,10,15$, or $20 \%$. The temperature limits of growth were determined by incubating cultures in liquid GPY nutrient media at temperatures of $+2,+4,+10,+25,+37,+45$, or $+50{ }^{\circ} \mathrm{C}$. The cultures were analyzed after ten days of incubation. At +2 and $+4{ }^{\circ} \mathrm{C}$ the incubation times were 30 and 60 days, respectively. The physiological properties of the few strains were not studied because they grew in pure culture very poorly and had low biomass. 


\subsection{Irradiation of Pure Bacterial Cultures with Gamma Radiation}

Several bacterial strains (KBP.AS.301, KBP.AS.319, KBP.AS.323, KBP.AS.324, KBP.AS.341, KBP.AS.343, KBP.AS.347) isolated from control and irradiated samples, and also strains Arthrobacter polychromogenes SN_T61 and Kocuria rosea SN_T60, as well as Deinococcus radiodurans VKM B-1422T were irradiated with gamma radiation under conditions that were close to normal. This was done to compare radioresistance of isolated pure cultures with that one the same bacteria irradiated in situ in soil and permafrost samples as well as for comparison of their radioresistance with the data of other authors. Prior irradiation bacterial biomass in stationary growth phase was immobilized in sterile kaolinite, as described in Section 2.2.

The irradiation was carried out on a gamma facility "Issledovatel" (USSR) with a ${ }^{60}$ Co source at a radiation intensity of $6.7 \mathrm{kGy} / \mathrm{h}$, normal atmospheric pressure and a temperature of $+37^{\circ} \mathrm{C}$ (the temperature was measured with a thermocouple) with a doses gradient of 4.7, 9.3, 14, 18.6, 28, 37.2 , and $46.5 \mathrm{kGy}$. The doses were selected in accordance with known data on the radiation resistance of bacteria [52,53], and the increased survivability of dried cultures [54,55]. Culturing from irradiated and control samples was performed, as described in Section 2.5 .

\section{Results and Discussion}

\subsection{Bacteria Abundance in the Samples}

Exposure to low temperature and low pressure did not affect the number of colony forming units (CFU) and the total number of prokaryotes.

Irradiation with accelerated electrons led to a decrease in the CFU number in the arid soil and permafrost by a one and more than three orders of magnitude, respectively (Figure 2). The total number of prokaryotic cells (EFM) in arid soil decreased 1.5 and 20 times after irradiation with doses of $10 \mathrm{kGy}$ and $100 \mathrm{kGy}$, respectively. In the permafrost sample, the total number of cells remained at the control level after irradiation with $100 \mathrm{kGy}$. That is, in terms of the total cells abundance the permafrost microbial community showed a higher survivability than the arid soil's one, which may be due to the accumulation of high radiation doses by microorganisms during natural cryopreservation in the permafrost [56] or by special protective properties of the organomineral substrate. It is shown that bacteria are able to increase radioresistance when exposed to radiation [57,58]. A more drastic decrease in the number of CFU in permafrost can be associated with both cell death and their passage to the unculturable state. The transition of prokaryotes to the unculturable or dormant state appears to be a common adaptation in the microbial communities of permafrost [59,60]. In particular, a recently published study in the Dry Valleys of Antarctica [60] revealed that microbial permafrost communities are enriched in genes that are involved with dormancy and sporulation. In such habitats, bacteria can have an increased readiness to transition to the unculturable state under the influence of various stress factors.

Culturable cells were not found in the control sample of montmorillonite, which indicates that there was no contamination during the experiment. Biological activity in this sample was also not detected by the EFM and MST methods.

\subsection{Metabolic Activity of Microbial Communities}

Microbial communities of control samples of arid soil and permafrost had high functional diversity and high potential metabolic activity and was able to consume 26 and 23 substrates, respectively. Exposure to low pressure and low temperature without irradiation did not affect the metabolic activity of the soil microbial community (Table 2). Irradiation with even a minimal dose (10 kGy) led to a sharp suppression of the potential metabolic activity: microbial communities of all the irradiated samples consumed only one substrate-peptone. Perhaps this was due to the fact that the peptone contains many different amino acids, while the remaining substrates were represented by pure substances. 
Accordingly, more different types of microorganisms are able to consume peptone in comparison with other substrates.

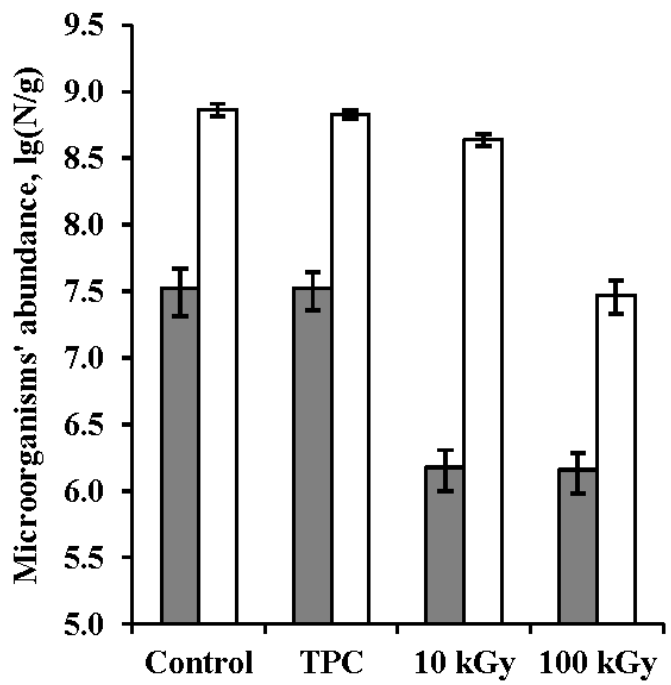

(a)

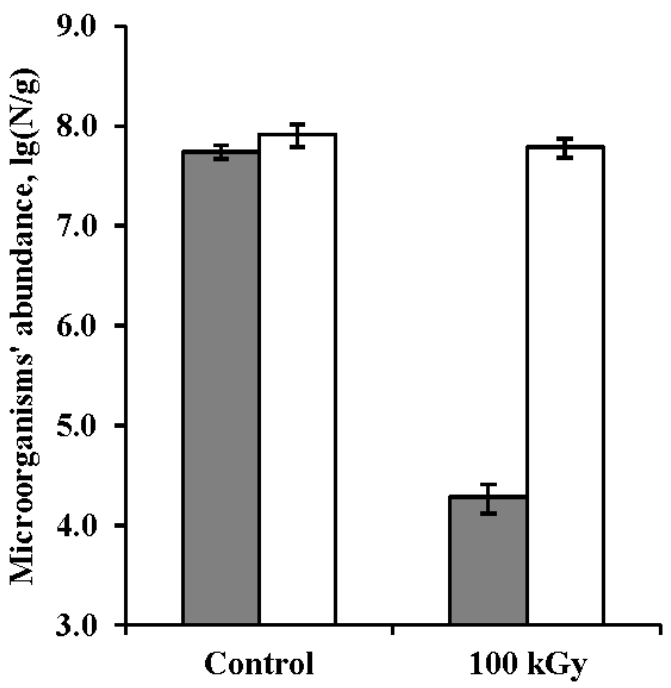

(b)

Figure 2. Impact of irradiation, low pressure, and low temperature on microbial abundance in (a) Arid soil samples; (b) Permafrost samples. Gray columns-Number of colony forming units, white columns-Total number of prokaryotes (EFM). TPC (Temperature and Pressure Control)—The sample, exposed to the low pressure and low temperature without irradiation. The error bars are within the standard deviation, $p<0.05$.

Table 2. Consumption of different classes of substrates by microbial communities at Multisubstrate Testing (MST). TPC-The sample, exposed to the low pressure and low temperature without irradiation.

\begin{tabular}{ccccccccc}
\hline & \multicolumn{7}{c}{ Consumption of Substrates of Different Groups, Relative Units } \\
\cline { 2 - 8 } Sample & Pentoses & Hexoses & Oligoses & Alcohols & $\begin{array}{c}\text { Amino } \\
\text { Acids }\end{array}$ & $\begin{array}{c}\text { Salts of } \\
\text { Carboxylic Acids }\end{array}$ & $\begin{array}{c}\text { Polymers } \\
\text { Amides, Amines, } \\
\text { Nucleosides }\end{array}$ \\
\hline SN2, Control & 526 & 3950 & 5340 & 4910 & 6186 & 3894 & 2654 & 124 \\
SN2, TPC & 544 & 3972 & 5294 & 4862 & 6268 & 3754 & 2716 & 132 \\
SN2, 10 kGy & 0 & 0 & 0 & 0 & 0 & 0 & 0 & 122 \\
SN2, 100 kGy & 0 & 0 & 0 & 0 & 0 & 0 & 3642 & 22 \\
M-1/91, Control & 2150 & 1420 & 1912 & 2562 & 5670 & 4318 & 0 & 0 \\
M-1/91, 100 kGy & 0 & 0 & 0 & 0 & 0 & 0 & 146 \\
\hline
\end{tabular}

\subsection{Taxonomic Affiliation and Physiological Characteristics of Bacterial Isolates}

The diversity of bacterial complexes cultured from soil samples after exposure at low temperature and pressure without irradiation and after irradiation with doses of $10 \mathrm{kGy}$ and $100 \mathrm{kGy}$ ( 0.01 Torr, $-130{ }^{\circ} \mathrm{C}$ ) decreased slightly after irradiation (Table 3, Table A2 in Appendix B). Based on the morphological features, 10, 8, and 9 strains were isolated from the mentioned variants of the arid soil, respectively (Table 3). However, the taxonomic composition of cultured communities differed significantly after different impacts. Thus, representatives of the genera Arthrobacter, Bacillus, Cryobacterium, Microbacterium, Micrococcus, Phenylobacterium, Saccharothrix, Sphingoaurantiacus, and Streptomyces were found in the sample exposed at low pressure and temperature without irradiation. After irradiation with $10 \mathrm{kGy}$, bacteria belonging to the genera Arthrobacter, Massilia, Micrococcus, Planomicrobium, Rufibacter, and Spirosoma were cultured from the same arid soil, and after irradiation with a dose of 100 kGy the genera Arthrobacter, Microvirga, Pontibacter, Rufibacter, and Spirosoma were revealed. At the same time, strains with $100 \%$ similarity of DNA sequences and identical morphology of colonies and cells were found among microbial isolates from different variants of SN2 sample. In particular, identical representatives of the genus Arthrobacter (strains KBP.AS.346, KBP.AS.300, 
KBP.AS.323) were found in all three variants. Arthrobacter of another species (KBP.AS.531, KBP.AS.533), as well as Micrococcus (KBP.AS.344, KBP.AS.534), identical with each other were detected both after exposure at low pressure and temperature without irradiation, and after irradiation with $10 \mathrm{kGy}$. In the arid soil samples that were irradiated with different doses, identical representatives of the genus Spirosoma (KBP.AS.298, KBP.AS.297) were found. Among all of the isolates, four strains (KBP.AS.345, KBP.AS.321, KBP.AS.535, KBP.AS.326) showed a fairly low similarity of the $16 \mathrm{~S}$ rRNA gene sequences to the GenBank database (about $98 \%$ and below), which allows for assuming that these strains belong to previously not described bacterial species. A detailed study of these strains is being conducted now by the authors of the present research. An interesting fact is also the finding of Cryobacterium in the desert soil (strain KBP.AS.341). Bacteria of this genus were previously isolated from cold habitats [61-63]; there is no information on Cryobacterium culturing from hot habitats in the scientific literature.

Table 3. Taxonomic affiliation of bacteria isolated from arid soil and permafrost. The strains, marked with identical superscript numbers have similar colony morphology and identical nucleotide sequences. The strains highlighted in bold have $<98 \%$ nucleotide sequences similarity with GenBank and possibly are the bacterial species not described earlier. TPC—The sample, exposed to the low pressure and low temperature without irradiation.

\begin{tabular}{|c|c|c|c|}
\hline Sample & $\begin{array}{l}\text { Strain-Genbank } \\
\text { Accession Number }\end{array}$ & $\begin{array}{l}\text { The Most Closely Related Sequences in } \\
\text { Genbank-Similarity, \% }\end{array}$ & Taxonomic Affiliation \\
\hline SN2, TPC & KBP.AS.531 MH050938 & $\begin{array}{c}\text { JX949673 Arthrobacter sp._-100 } \\
\text { NR_026198 Arthrobacter agilis—99.5 } \\
\text { NR_148833 Arthrobacter echini-99.3 } \\
\text { JQ419609 Saccharothrix sp.—99.8 }\end{array}$ & Arthrobacter sp. ${ }^{1}$ \\
\hline SN2, TPC & KBP.AS.532 MH050939 & $\begin{array}{l}\text { NR_109447 Saccharothrix ecbatanensis-99.5 } \\
\text { NR_109103 Saccharothrix hoggarensis—99.5 } \\
\text { KJ578028 Uncultured bacterium clone-99.9 }\end{array}$ & Saccharothrix sp. \\
\hline SN2, TPC & KBP.AS.340 MH050940 & $\begin{array}{c}\text { KT191026 Phenylobacterium panacis_-99.5 } \\
\text { NR_117783 Phenylobacterium } \\
\text { muchangponense_-99.5 }\end{array}$ & Phenylobacterium sp. \\
\hline & & $\begin{array}{l}\text { DQ177485 Microbacteriaceae bacterium-99.6 } \\
\text { KR857373 Cryobacterium sp.—99.4 }\end{array}$ & \\
\hline SN2, TPC & KBP.AS.341 MH050941 & FR691394 Cryobacterium sp.--99.4 & Cryobacterium sp. \\
\hline & & $\begin{array}{c}\text { NR_108605 Cryobacterium arcticum-99.4 } \\
\text { JX205201 Cryobacterium psychrotolerans—99.2 }\end{array}$ & \\
\hline SN2, TPC & KBP.AS.342 MH050942 & $\begin{array}{c}\text { KY820858 Streptomyces fulvissimus-99.3 } \\
\text { AJ781354 Streptomyces mediolani-99.3 }\end{array}$ & Streptomyces sp. \\
\hline SN2, TPC & KBP.AS.343 MH050943 & $\begin{array}{l}\text { NR_119270 Microbacterium saperdae-100 } \\
\text { NR_025405 Microbacterium phyllosphaerae-100 } \\
\text { GQ232449 Bacterium RK91_tank-100 }\end{array}$ & Microbacterium sp. \\
\hline SN2, TPC & KBP.AS.344 MH050944 & $\begin{array}{c}\text { JN378531 Micrococcus luteus-99.9 } \\
\text { NR_134088 Micrococcus aloeverae-99.7 }\end{array}$ & Micrococcus sp. ${ }^{2}$ \\
\hline & & $\begin{array}{l}\text { NR_116578 Micrococcus yunnanensis-99.6 } \\
\text { DQ906916 Uncultured bacterium clone-99.4 }\end{array}$ & \\
\hline SN2, TPC & KBP.AS.345 MH050945 & $\begin{array}{c}\text { NR_147725 Sphingoaurantiacus } \\
\text { polygranulatus-96.8 } \\
\text { NR_148321 Sphingomonas } \\
\text { chloroacetimidivorans-95.4 }\end{array}$ & Sphingoaurantiacus sp. \\
\hline & & $\begin{array}{l}\text { KT321369 Sphingoaurantiacus capsulatus-95.3 } \\
\text { IX840970 Arthrobacter oxydans-100 }\end{array}$ & \\
\hline SN2, TPC & KBP.AS.346 MH050946 & $\begin{array}{c}\text { NR_108849 Arthrobacter siccitolerans—99.7 } \\
\text { NR_026192 Arthrobacter polychromogenes_-99.6 }\end{array}$ & Arthrobacter sp. ${ }^{3}$ \\
\hline SN2, TPC & KBP.AS.347 MH050947 & $\begin{array}{l}\text { NR_117474 Bacillus frigoritolerans-100 } \\
\text { NR_114919 Bacillus simplex-100 }\end{array}$ & Bacillus sp. \\
\hline SN2, 10 kGy & KBP.AS.298 MH050948 & $\begin{array}{l}\text { NR_113978 Spirosoma rigui_-99.8 } \\
\text { EF507901 Spirosoma aquatica-99.8 }\end{array}$ & Spirosoma sp. ${ }^{4}$ \\
\hline SN2, 10 kGy & KBP.AS.299 МH050949 & $\begin{array}{l}\text { AB637009 Uncultured bacterium clone-100 } \\
\text { HG316123 Rufibacter immobilis-99 } \\
\text { CP012645 Rufibacter tibetensis-97.8 }\end{array}$ & Rufibacter immobilis \\
\hline
\end{tabular}


Table 3. Cont.

\begin{tabular}{|c|c|c|c|}
\hline Sample & $\begin{array}{l}\text { Strain-Genbank } \\
\text { Accession Number }\end{array}$ & $\begin{array}{c}\text { The Most Closely Related Sequences in } \\
\text { Genbank-Similarity, \% }\end{array}$ & Taxonomic Affiliation \\
\hline SN2, 10 kGy & KBP.AS.300 MH050950 & $\begin{array}{c}\text { NR_042469 Arthrobacter } \\
\text { phenanthrenivorans-100 } \\
\text { NR_117356 Arthrobacter cryotolerans-100 } \\
\text { NR_041546 Arthrobacter humicola-100 }\end{array}$ & Arthrobacter sp. ${ }^{3}$ \\
\hline SN2, 10 kGy & KBP.AS.533 MH050951 & $\begin{array}{l}\text { KY386623 Arthrobacter sp.-100 } \\
\text { NR_026198 Arthrobacter agilis-100 } \\
\text { NR_148833 Arthrobacter echini-99.6 } \\
\text { HQ860629 Uncultured bacterium clone-100 }\end{array}$ & Arthrobacter sp. ${ }^{1}$ \\
\hline SN2, 10 kGy & KBP.AS.301 MH050952 & $\begin{array}{l}\text { GQ140340 Planomicrobium okeanokoites_-99.9 } \\
\text { NR_116601 Planomicrobium flavidum—99.7 } \\
\text { HQ860629 Uncultured bacterium clone—100 }\end{array}$ & Planomicrobium sp. ${ }^{5}$ \\
\hline SN2, 10 kGy & KBP.AS.302 MH050953 & $\begin{array}{l}\text { GQ140340 Planomicrobium okeanokoites—99.9 } \\
\text { NR_116601 Planomicrobium flavidum—99.7 } \\
\text { FR675946 Uncultured bacterium clone_-99.5 }\end{array}$ & Planomicrobium sp. ${ }^{5}$ \\
\hline SN2, 10 kGy & KBP.AS.303 MH050954 & $\begin{array}{c}\text { NR_117040 Massilia consociata_-99.0 } \\
\text { NR_042502 Massilia aurea—98.4 } \\
\text { NR_126273 Massilia kyonggiensis_98.4 }\end{array}$ & Massilia sp. \\
\hline SN2, 10 kGy & KBP.AS.534 MH050955 & $\begin{array}{l}\text { NR_134088 Micrococcus aloeverae-99.8 } \\
\text { NR_116578 Micrococcus yunnanensis—99.8 }\end{array}$ & Micrococcus sp. ${ }^{2}$ \\
\hline SN2, 100 kGy & KBP.AS.297 MH050956 & $\begin{array}{c}\text { NR_113978 Spirosoma rigui-99.8 } \\
\text { EF507901 Spirosoma aquatica-99.8 }\end{array}$ & Spirosoma sp. ${ }^{4}$ \\
\hline SN2, 100 kGy & KBP.AS.321 MH050957 & $\begin{array}{c}\text { JF417863 Uncultured bacterium clone-97.9 } \\
\text { HG316124 Rufibacter immobilis-96.8 } \\
\text { NR_116350 Rufibacter tibetensis—96.3 }\end{array}$ & Rufibacter sp. \\
\hline SN2, 100 kGy & KBP.AS.322 MH050958 & $\begin{array}{l}\text { HQ910259 Uncultured bacterium clone-99.6 } \\
\text { JX504809 Microvirga vignae—98.7 } \\
\text { NR_114298 Microvirga aerilata—98.7 } \\
\text { KC354446 Arthrobacter sp.—100 }\end{array}$ & Microvirga sp. \\
\hline SN2, 100 kGy & KBP.AS.323 MH050959 & $\begin{array}{l}\text { JX840970 Arthrobacter oxydans-100 } \\
\text { NR_108849 Arthrobacter siccitolerans—99.7 } \\
\text { KX247636 Microvirga soli-99.7 }\end{array}$ & Arthrobacter sp. ${ }^{3}$ \\
\hline SN2, 100 kGy & KBP.AS.324 MH050960 & $\begin{array}{l}\text { JF295810 Uncultured bacterium clone-99 } \\
\text { HF954468 Microvirga sp.-98 } \\
\text { NR_104766 Microvirga subterranea-97.9 }\end{array}$ & Microvirga soli \\
\hline SN2, 100 kGy & KBP.AS.325 MH050961 & $\begin{array}{l}\text { NR_042252 Arthrobacter parietis-100 } \\
\text { KP125973 Arthrobacter subterraneus-100 } \\
\text { FR691450 Pontibacter sp.-99.1 }\end{array}$ & Arthrobacter sp. \\
\hline $\mathrm{SN} 2,100 \mathrm{kGy}$ & KBP.AS.535 MH050962 & $\begin{array}{l}\text { NR_148858 Pontibacter amylolyticus-98.1 } \\
\text { NR_116853 Pontibacter salisaro-97.9 }\end{array}$ & Pontibacter sp. \\
\hline SN2, 100 kGy & KBP.AS.536 MH050963 & $\begin{array}{l}\quad \text { KX247636 Microvirga soli-99.4 } \\
\text { NR_044563 Microvirga guangxiensis-99.1 }\end{array}$ & Microvirga sp. \\
\hline SN2, 100 kGy & KBP.AS.326 MH050964 & $\begin{array}{l}\text { AJ863207 Uncultured bacterium clone-99 } \\
\text { KX350156 Pontibacter sp.-99.0 } \\
\text { JN037908 Uncultured Bacteroidetes } \\
\text { bacterium—98.2 } \\
\text { NR } 133822 \text { Pontibacter deserti-97.5 }\end{array}$ & Pontibacter sp. \\
\hline M-1/91, 100 kGy & KBP.AS.317 MH050965 & $\begin{array}{c}\text { NR_109067 Pontibacter populi-96.3 } \\
\text { KJ000846 Brevundimonas sp.—99.9 } \\
\text { NR_116722 Brevundimonas } \\
\text { naejangsanensis—99.9 } \\
\text { NR_113602 Brevundimonas diminuta_99.7 }\end{array}$ & Brevundimonas sp. \\
\hline M-1/91, 100 kGy & KBP.AS.319 MH050966 & $\begin{array}{l}\text { NR_114986 Microbacterium maritypicum-100 } \\
\text { KT899483 Microbacterium oxydans-100 }\end{array}$ & Microbacterium sp. ${ }^{7}$ \\
\hline M-1/91, 100 kGy & KBP.AS.320 MH050967 & $\begin{array}{l}\text { NR_114986 Microbacterium maritypicum-100 } \\
\text { KT899483 Microbacterium oxydans_-100 }\end{array}$ & Microbacterium sp. ${ }^{7}$ \\
\hline M-1/91, 100 kGy & KBP.AS.537 MH050968 & $\begin{array}{l}\text { HM811712 Uncultured bacterium-99.5 } \\
\text { NR_121739 Stenotrophomonas rhizophila—99.2 } \\
\text { LT906480 Stenotrophomonas maltophilia—97.9 }\end{array}$ & $\begin{array}{l}\text { Stenotrophomonas } \\
\text { rhizophila }\end{array}$ \\
\hline
\end{tabular}

Diversity of bacteria that were cultured from the irradiated permafrost sample was significantly lower than in arid soil. Four bacterial strains belonging to three genera were identified: Brevundimonas, Microbacterium, and Stenotrophomonas.

The isolation of bacteria of the genus Arthrobacter after irradiation is in complete agreement with the previously obtained data on their high radioresistance in situ to gamma radiation under the 
model conditions of Mars [6], as well as with data on their high radioresistance in pure culture [64] and with data on their high ultraviolet resistance [65]. There is also data on the high radioresistance of the Spirosoma [66], Pontibacter, Rufibacter, Microvirga [64], Micrococcus [67], Planomicrobium [64,68], Massilia [69], Brevundimonas [10], and Stenotrophomonas [70]. We have not been able to find information about the high radioresistance of Microbacterium. A number of studies have shown that bacteria of this genus have a high resistance to ultraviolet radiation and have multiple stress tolerance [70-73]. Thus, all the heterotrophic aerobic bacteria that were isolated from the samples irradiated with accelerated electrons belong to genera for which high radioresistance or high resistance to ultraviolet radiation is known.

Most of the isolated strains, including arid soil isolates, showed facultative-psychrophilic (psychotropic) properties, that is, they could grow in the temperature range extended to the low-temperature (Table 4). This can be both a manifestation of adaptation to storage and exposure of samples at low temperatures, and the increased resistance of psychrophiles to oxidative stress [74], and, consequently, to radiation. According to the data on resistance to $\mathrm{pH}$, neutrophiles with wide pH-ranges of growth (4-12), alkalophiles (8-12), and acid-tolerant alkalophiles $(4-8,5-9)$ were found among isolates. Recall that the samples had a slightly alkaline $\mathrm{pH}$ (Table 1 ). The variety of $\mathrm{pH}$-ranges of growth probably reflects the heterogeneity of the soil environment. However, it is noteworthy that most of the isolated strains are resistant to the acidity of the medium and grow in a wide $\mathrm{pH}$ range.

Table 4. Physiological characteristics of bacteria isolated from arid soil and permafrost. TPC-The sample, exposed to the low pressure and low temperature without irradiation.

\begin{tabular}{|c|c|c|c|c|c|c|c|c|}
\hline \multirow[t]{2}{*}{ Sample } & \multirow[t]{2}{*}{ Strain } & \multirow[t]{2}{*}{ Taxonomic Affiliation } & \multirow{2}{*}{$\begin{array}{l}\text { Temperature } \\
\text { Limits of } \\
\text { Growth, }{ }^{\circ} \mathrm{C}\end{array}$} & \multirow{2}{*}{$\begin{array}{l}\text { pH-range of } \\
\text { Growth }\end{array}$} & \multicolumn{4}{|c|}{$\begin{array}{l}\text { Maximum Salt Concentrations at } \\
\text { Which Growth Is Possible, \% }\end{array}$} \\
\hline & & & & & $\mathrm{NaCl}$ & $\mathrm{KCl}$ & $\mathrm{MgSO}_{4}$ & $\mathrm{NaHCO}_{3}$ \\
\hline SN2, TPC & KBP.AS.532 & Saccharothrix sp. & $10-37$ & $4-12$ & 2 & 5 & 20 & 0 \\
\hline SN2, TPC & KBP.AS.340 & Phenylobacterium sp. & $10-37$ & $6-12$ & 0 & 0 & 5 & 0 \\
\hline SN2, TPC & KBP.AS.341 & Cryobacterium sp. & $2-37$ & $7-11$ & 20 & 15 & 20 & 0 \\
\hline SN2, TPC & KBP.AS.344 & Micrococcus sp. & $10-37$ & $5-8$ & 0 & 5 & 0 & 0 \\
\hline SN2, TPC & KBP.AS.346 & Arthrobacter sp. & $2-50$ & $6-10$ & 0 & 0 & 2 & 0 \\
\hline SN2, TPC & KBP.AS.347 & Bacillus sp. & $2-37$ & $5-8$ & 0 & 5 & 0 & 0 \\
\hline SN2, 10 kGy & KBP.AS.298 & Spirosoma sp. & $10-37$ & $5-12$ & 20 & 15 & 20 & 0 \\
\hline SN2, 10 kGy & KBP.AS.299 & Rufibacter immobilis & $2-37$ & $6-8$ & 0 & 0 & 2 & 0 \\
\hline SN2, 10 kGy & KBP.AS.303 & Massilia sp. & $10-37$ & $5-8$ & 0 & 0 & 0 & 0 \\
\hline SN2, 10 kGy & KBP.AS.534 & Micrococcus sp. & $10-37$ & 5-12 & 20 & 15 & 20 & 0 \\
\hline SN2, 100 kGy & KBP.AS.297 & Spirosoma sp. & $10-37$ & $7-12$ & 0 & 0 & 0 & 2 \\
\hline SN2, 100 kGy & KBP.AS.323 & Arthrobacter sp. & $4-37$ & $8-12$ & 5 & 0 & 0 & 2 \\
\hline SN2, 100 kGy & KBP.AS.324 & Microvirga sp. & $4-37$ & $7-12$ & 10 & 15 & 20 & 0 \\
\hline SN2, 100 kGy & KBP.AS.325 & Arthrobacter sp. & $2-50$ & $5-12$ & 0 & 5 & 15 & 0 \\
\hline M-1/91, 100 kGy & KBP.AS.317 & Brevundimonas sp. & $10-37$ & $5-12$ & 20 & 15 & 20 & 0 \\
\hline M-1/91, 100 kGy & KBP.AS.319 & Microbacterium sp. & $10-37$ & $5-8$ & 2 & 2 & 2 & 0 \\
\hline M-1/91, 100 kGy & KBP.AS.320 & Microbacterium sp. & $4-50$ & $7-12$ & 0 & 0 & 2 & 0 \\
\hline M-1/91, 100 kGy & KBP.AS.537 & $\begin{array}{l}\text { Stenotrophomonas } \\
\text { rhizophila }\end{array}$ & $2-37$ & $6-11$ & 0 & 0 & 5 & 2 \\
\hline
\end{tabular}

Some strains were sensitive to the presence of salts in the medium, others were halotolerant and grew with a content of up to $20 \% \mathrm{NaCl}$ or $\mathrm{MgSO}_{4}$ and up to $15 \% \mathrm{KCl}$ in the medium (Table 4). Bacterial strains practically did not grow on media containing $\mathrm{NaHCO}_{3}$, even in small concentrations. Correlations between resistance to the studied physical and chemical factors ( $\mathrm{T}, \mathrm{pH}$, salts) and radioresistance were not observed. 


\subsection{Irradiation of Pure Bacterial Cultures with Accelerated Electrons under Simulated Extraterrestrial Conditions}

To assess the protective role of the natural environment and interpopulation relations in situ to protect microorganisms from radiation, irradiation of strains Arthrobacter polychromogenes SN_T61 and Kocuria rosea SN_T60 with accelerated electrons under low pressure and low temperature conditions was carried out. Pure bacterial cultures were immobilized in a mineral matrix, according to the protocol described in Section 2.2.

Low temperature and low-pressure conditions had practically no impact on the number of CFU (Figure 3). After irradiation with a dose of $10 \mathrm{kGy}$, the number of CFUs of A. polychromogenes SN_T61 and K. rosea SN_T60 decreased by three and four orders of magnitude, respectively. After irradiation with a dose of $100 \mathrm{kGy}$, no cultured cells were detected. Pure cultures showed significantly less resistance to radiation than microbial communities in situ. Such a result can be caused by features of a heterogeneous soil environment, as well as by interactions of microorganisms within the community.

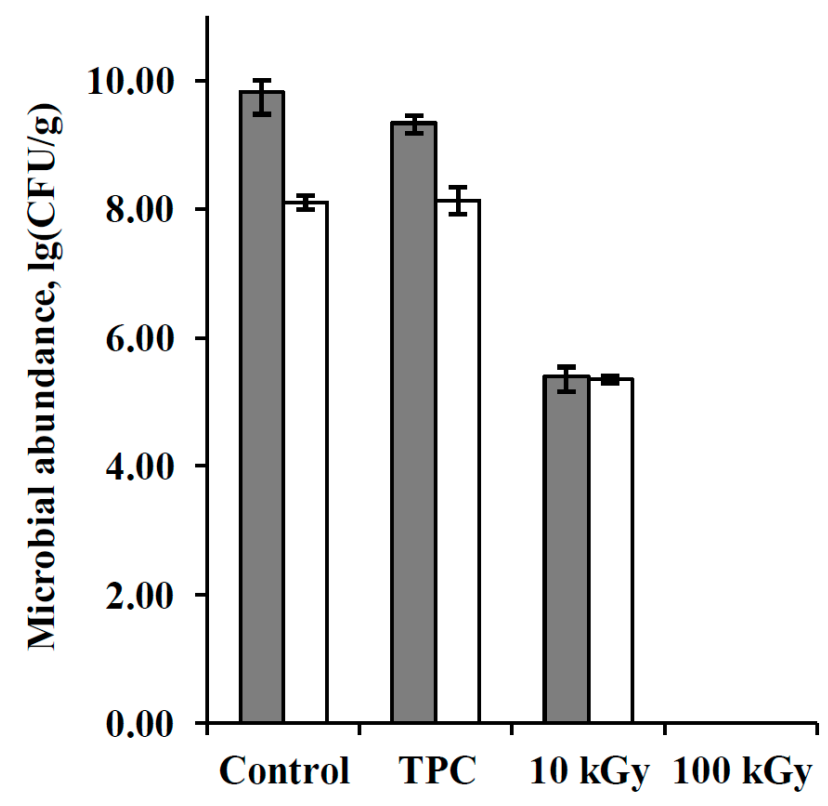

Figure 3. Impact of accelerated electrons, low pressure, and low temperature on the colony forming units' number of pure bacterial cultures. Gray columns-Arthrobacter polychromogenes SN_T61, white columns-Kocuria rosea SN_T60. TPC—The samples, exposed to the low pressure and low temperature without irradiation. The error bars are within the standard deviation, $p<0.05$.

The soil is an extremely heterogeneous environment [75-77]. The physicochemical conditions in this environment can drastically change on a micro scale. That is, the soil is a combination of microzones with various conditions-different concentrations of water, oxygen, organic substances, salts, minerals, etc. As mentioned above, the physicochemical conditions at irradiation can affect the radiation damage of microorganisms. Probably, in the soil with its high heterogeneity, there should exist niches most favorable for the survival of bacteria upon irradiation. Also soils contain various organics, including pigments and microbial's growth autoregulators. It is shown that these substances play an important role in the stress tolerance of microorganisms [18,78-81]. There is also information on the higher radioresistance of microorganisms in soils with high concentrations of humus, but these data are contradictory [82].

It is shown that bacteria within biofilms have increased resistance to stress in comparison with planktonic cells $[16,17]$. The protective role of intra- and interpopulation interactions can also be manifested through the production of some metabolites, as mentioned above. Moreover, 
microorganisms possess the quorum-sensing, which also contributes to resistance to adverse effects, in particular, to oxidative stress [18,83].

These factors, as well as possibly some unrevealed factors, may correct the radioresistance of microorganisms in situ. However, it should be noted that the role of these factors in the radioresistance of natural microbial communities is currently poorly understood.

\subsection{Survivability of Pure Bacterial Cultures under Gamma Irradiation}

Another series of bacterial strains were irradiated with gamma radiation under normal conditions. Some of the strains were isolated from the studied arid soil and permafrost samples after irradiation with high radiation doses and after exposure to the simulated extraterrestrial conditions (Table 5). There were seven such strains, and Arthrobacter polychromogenes SN_T61 and Kocuria rosea SN_T60 isolated earlier from arid soil (see Section 2.1) were irradiated along with them, and Deinococcus radiodurans VKM B-1422T strain was simultaneously irradiated for comparison. Viable cells of $D$. radiodurans VKM B-1422T were detected after irradiation with doses up to $28 \mathrm{kGy}$ inclusive. Of the remaining nine strains, only two (Bacillus sp. KBP.AS.347 and Planomicrobium sp. KBP.AS.301) survived the irradiation with a minimal dose of $4.7 \mathrm{kGy}$, but these two strains did not withstand higher doses (Figure 4). It should be noted that resistance to $4.7 \mathrm{kGy}$ dose allows for these strains to be considered radioresistant [11]. However, most strains did not show high radioresistance. Taking into account that some strains were isolated from the samples after irradiation with various high doses of accelerated electrons, it becomes evident that as the part of natural microbial communities, even radiosensitive microorganisms are able to withstand exposure to high radiation doses. This agrees with the data of Section 3.4 and also confirms the assumption that the natural organomineral heterophase medium has a protective function for the microorganisms inhabiting it, as well as, possibly, interrelationships in the community itself. Survival of soil microorganisms after exposure to high radiation doses ( $15 \mathrm{kGy})$ in the absence of the same high radioresistance in isolates was observed by other researchers [84]. In such studies, isolated strains that are offspring of irradiated in situ in soil microorganisms may carry residual genetic disturbances. However, as already mentioned, it has been experimentally shown that repeated irradiation of bacterial cultures leads to adaptation and enhancement, rather than a decrease in their radioresistance $[57,58]$. Thus, we demonstrated a much higher resistance of bacteria in situ in the composition of microbial communities in the natural habitat when compared to their resistance in pure culture.

Table 5. List of the strains irradiated with gamma radiation under normal conditions. TPC-The samples, exposed to the low pressure and low temperature without irradiation.

\begin{tabular}{ccc}
\hline Sample & Strain Number & Taxonomic Affiliation \\
\hline SN2, TPC & KBP.AS.341 & Cryobacterium sp. \\
SN2, TPC & KBP.AS.343 & Microbacterium sp. \\
SN2, TPC & KBP.AS.347 & Bacillus sp. \\
SN2, 10 kGy & KBP.AS.301 & Planomicrobium sp. \\
SN2, $100 \mathrm{kGy}$ & KBP.AS.323 & Arthrobacter sp. \\
SN2, $100 \mathrm{kGy}$ & KBP.AS.324 & Microvirga sp. \\
M-1/91, 100 kGy & KBP.AS.319 & Microbacterium sp. \\
SN $^{1}$ & SN_T60 & Kocuria rosea \\
SN ${ }^{1}$ & SN_T61 & Arthrobacter polychromogenes \\
The strain obtained from the VKM collection & VKM B-1422T & Deinococcus radiodurans \\
\hline
\end{tabular}

When comparing the radioresistance of $A$. polychromogenes SN_T61 and K. rosea SN_T60 at irradiation under normal conditions and at low temperature and low pressure demonstrates a sharp decrease in radiation damage in the model conditions of Mars and outer space. The strains survived $10 \mathrm{kGy}$ under model conditions, while retaining a high number of cells, but it did not survive $4.7 \mathrm{kGy}$ 
under normal conditions. This is probably due to a decrease in the activity of free radicals with a decrease in temperature [10], as well as a decrease in the amount of water and oxygen, which are the main sources of free radicals [5,11], with a decrease in pressure. In addition, some differences may be due to the different types of radiation that we used.

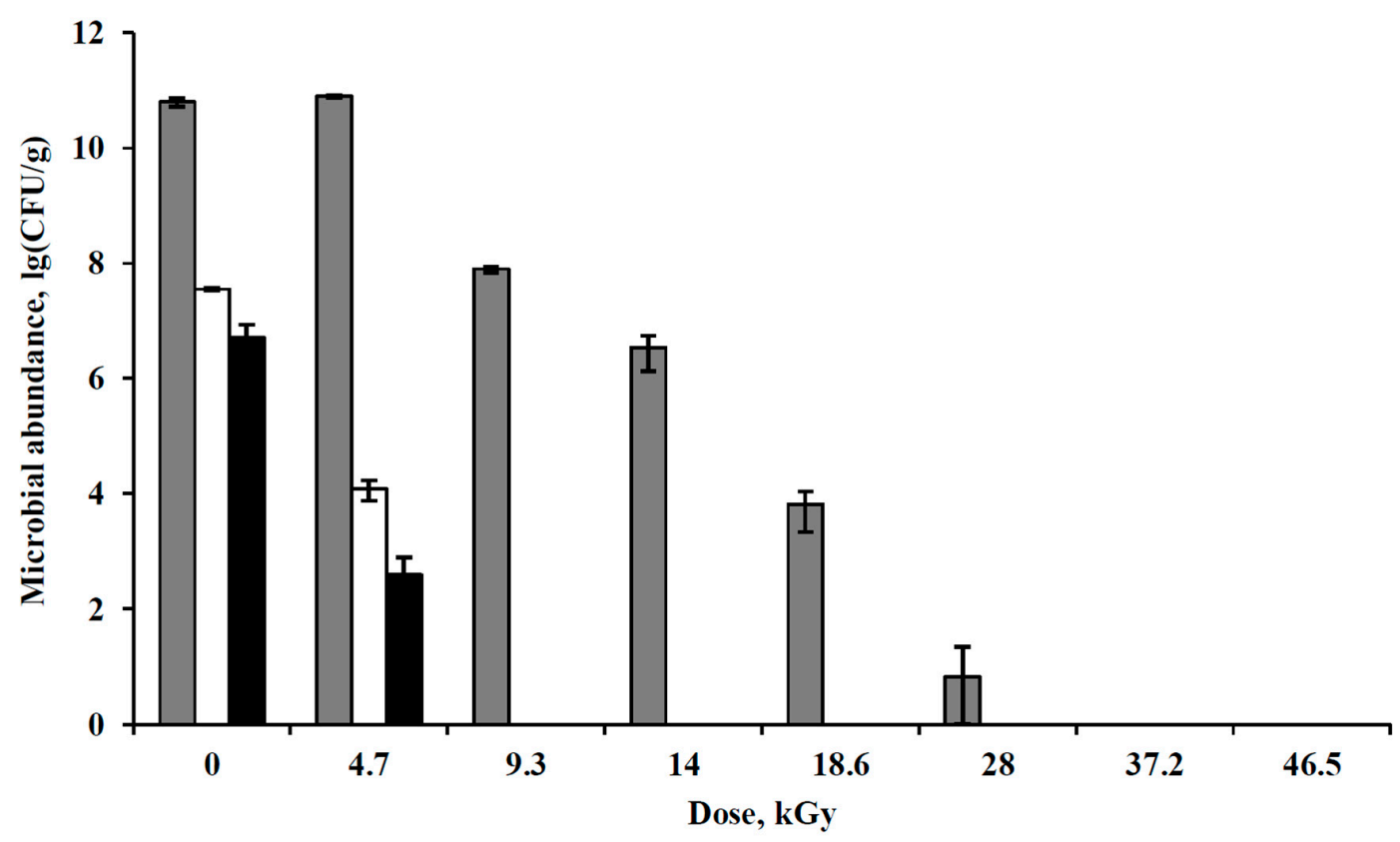

Figure 4. Impact of gamma radiation on the colony forming units' number of pure bacterial cultures. Gray columns-Deinococcus radiodurans VKM B-1422T, white columns-Bacillus sp. KBP.AS.347, black columns-Planomicrobium sp. KBP.AS.301. The strains that did not survive after even the minimal radiation dose are not shown. The error bars are within the standard deviation, $p<0.05$.

The high radioresistance of Planomicrobium in pure culture was previously shown only twice $[64,68]$. Our data indicate that high resistance to radiation might be characteristic to the entire genus Planomicrobium (or for many of its species).

It should be emphasized how much the combination of Mars physical factors and the natural environment corrects radioresistance- the strains that survived in situ as a part of microbial community after $100 \mathrm{kGy}$ irradiation (moreover, even those that retained high abundance after $100 \mathrm{kGy}$ irradiation) did not survive irradiation with $4.7 \mathrm{kGy}$ dose in pure culture under normal conditions. Thus, the microorganisms irradiated under simulated Martian conditions in soil in situ showed more than 20 times increased survivability when compared to pure bacterial cultures irradiated under normal conditions.

\subsection{Implications for Habitability Assessment}

The radiation resistance of microbial communities in our experiment was significantly higher than it is generally assumed $[53,82,84,85]$. This may be due to the reduction of radiation damage under low pressure and low temperature conditions $[5,10]$, and was discussed in detail in already published papers $[6,9]$.

The intensity of ionizing radiation on the surface of modern Mars is about 0.076 Gy/year [23]. $100 \mathrm{kGy}$ radiation dose can be accumulated in the surface layer of regolith for 1.3 million years. This suggests that microorganisms in the modern cold conditions of Mars (in the absence of the possibility of actively repairing radiation damages) are able to remain viable for the specified period. At $5 \mathrm{~m}$ depth, the radiation intensity is about $5 \mathrm{mGy} /$ year [20], and $100 \mathrm{kGy}$ dose can be accumulated after 20 million years. These estimates of the possible duration of viable conservation of the hypothetical 
deep Martian biosphere in the cryopreserved state coincide with those we indicated earlier [6]. It can also be assumed that viable microorganisms can be preserved in the ice of Europa for at least $~ 170$ years at $10 \mathrm{~cm}$ depth, taking into account the data on the radiation intensity of $\sim 600 \mathrm{~Gy} /$ year at this depth [5]. In this case, it should be noted that in our experiment the samples were dried, while the presence of water can significantly affect (advance) radiation damage $[5,11]$. The effect of ionizing radiation is also a limiting factor for the realization of some mechanisms of panspermia $[5,86,87]$. During a long journey of meteorites in outer space, hypothetical microorganisms that are located within them must accumulate high doses of radiation. It is estimated that most of the Martian meteorites reach Earth after thousands and millions of years of flight in open space [86]. Based on the radiation intensity inside meteorites, which is not more than $0.25 \mathrm{~Gy} /$ year depending on the size and material of the space body [87], the results of our study allow for hypothesizing the survival of microorganisms for at least 400 thousand years in open space (i.e., accumulation of $100 \mathrm{kGy}$ dose for this period). These data can be used to estimate the probability of interplanetary life transport.

We note that the irradiation intensity that was used in the experiment is by the several orders of magnitude higher than in extraterrestrial conditions $[20,23,86,87]$. It is shown that in general the effectiveness of sparsely ionizing radiation (including accelerated electrons) dose is decreases with irradiation intensity decreasing due to radiation damage repairing by cells [5]. In low-temperature conditions of open space and Europa, a cells' repairing seems unlikely [88]. So, differences in radiation intensity should not affect the survivability of microorganisms. But considering Mars, the possibility of cells' repairing should be taken into account. There are a lot of studies testifies possibility of it. Microbial metabolism is revealed at temperatures at least down to $-33{ }^{\circ} \mathrm{C}[88,89]$. Moreover, it is shown that econiches with liquid water and positive temperatures can occur on the current Mars [88,90-93]. Terrestrial microorganisms can grow under combined low pressure, temperature, and anoxic atmosphere conditions [94], it can withstand the impact of Martian salts and strong oxidizers [95-98], and can survive in subzero brines [99,100]. If even slow repairing of cells' damages occurs, it can be of great effect during geological time. Thus, it can be concluded that, on Mars, the extension of viable cells' in situ cryopreservation time should occur and be not fully compatible with our model experiment.

The age of Martian permafrost is evaluated at approximately more than $3 \mathrm{Ga}$ [24]. At the current intensity of ionizing radiation during $3 \mathrm{Ga}$, the putative microorganisms in the cryopreserved state should accumulate 230 MGy and $\sim 15$ MGy doses in the shallow layer of the regolith and at $5 \mathrm{~m}$ depth, respectively. This calculation suggests that survivability after irradiation with $100 \mathrm{kGy}$ dose is not enough for viable cryopreservation of the putative ancient biosphere of early Mars till present. But, this dose was not sterilizing in our study - the true sterilizing doses may be significantly higher. Definition of the microbial communities' radioresistance limit is in the scope of the further research. Nevertheless, survival of putative ancient biosphere over $3 \mathrm{Ga}$ in the cryopreserved state without cell replication or metabolism (i.e., without radiation damages repairing) seems unlikely. However, there are some possibilities for cells' repairing and viable cryopreservation time extension in conditions of the current Mars, as mentioned above. Moreover, there is evidence of the presence of liquid water and of atmosphere with higher temperature and pressure in the recent past of the Mars-hundreds of thousands and few millions of years ago [101-104]. Our data indicate that microorganisms should survive in the permafrost sediments of such ages, even at shallow depths.

Data on high radioresistance of microorganisms (including our earlier papers $[6-9,37]$ ) also indicates that putative contaminants that were carried with past and future space missions can survive on different space objects for a long time. Moreover, as discussed above, there are possibilities for microorganisms' growth and replication under current Martian conditions. Contaminants from shallow regolith layers might be widely spread on the planet by the dust storms [10], and this can significantly obstruct the search for the indigenous life on the Mars. Due to this, it is necessary to advance methods and protocols for reducing the microbial load on space missions. In particular, new antibacterial surfaces [105] and sterilization methods [106,107] are being developed. Since the results of the study 
presented testify in favor of the possibility of extraterrestrial life exists, they should be considered at sample return missions planning meaning appropriate protocols development and implementation in order to prevent Earth contamination.

Irradiation with accelerated electrons led to more damage of microbial communities than irradiation with the same gamma radiation doses under similar conditions $[6,7,33,38,39]$. This was expressed in a decrease in the total number of prokaryotes as determined by the EFM method, as well as in the sharp suppression of potential metabolic activity. This result is also confirmed with pure cultures: it was previously shown that strains of Arthrobacter polychromogenes SN_T61 and Kocuria rosea SN_T60 are able to withstand gamma irradiation under low pressure (1 Torr) and low temperature $\left(-50{ }^{\circ} \mathrm{C}\right)$ conditions with doses of at least $10 \mathrm{kGy}$ without a significant reduction number of viable cells $[38,39]$. Irradiation with accelerated electrons with $10 \mathrm{kGy}$ dose led to a decrease in CFU abundance by 3-4 orders of magnitude. It is necessary to study the effects of the entire spectrum of ionizing radiation, as well as to study the effect of higher radiation doses for a more accurate prediction of the duration of conservation of microorganisms and biomarkers at various objects of the Solar system and beyond.

The modern concept of the Mars evolution assumes a scenario of the planet's development according to the terrestrial type with the possible emergence of the biosphere [24-28]. The impact of radiation could contribute to the origin of life, being, possibly, a key factor [108]. The discovery of ancient ecosystems in palaeoarcheal sediments [109-112] suggests that life appeared very quickly after the formation of our planet, and it quickly spread on its surface. However, this was not the Earth familiar to us. The radiation of the young Sun was significantly higher than the current one [113-115]. In particular, X-ray and EUV emission was six and up to 1000 times stronger than those of the present Sun during $3.5 \mathrm{Ga}$ and $4.5 \mathrm{Ga}$, respectively. It is suggested, that the early Earth's surface was subjected to the high levels of cosmic ionizing and ultraviolet radiation, although there is uncertainty on the density of the early Earth's atmosphere [116], which could protect the planet surface against radiation. Moreover, the background from the decay of radioisotopes on the ground was about five times higher [117]. From the standpoint of modern scientific logic, life on such a planet is impossible. But, it arose and quickly evolved, improving the mechanisms of adaptation in a changing environment. The experience of the early evolution of life in the conditions of the young Earth (or outside it, in accordance with the hypothesis of panspermia) should be fixed in the genetic material of descendants of the primary biosphere [118]. This gives grounds for assumptions that the high stability of the currently observed effects of adaptation of biosystems to cosmo-geophysical impacts are atavisms of the geological epoch of the much more active early Sun $[119,120]$. Similarly, the biosphere could arise and evolved on Mars, developing the processes of adapting life to the very harsh conditions of the planet at the initial stages of planet's development. At the same time, adaptive-genetic acquisitions of cells in the natural habitat could be accumulated and they could ensure a sustained life-support in a new round of unfavorable conditions with the loss of a significant part of the atmosphere by Mars. For a logically justified estimate of the duration of maintenance of a putative life in a Mars soil, the Earth model is the only object. Therefore, further research is needed on the conditions and limits of life that is embedded of the planetary body, using the example of study natural terrestrial biotopes.

\section{Conclusions}

We performed the study of viability of natural microbial communities of extreme habitats after irradiation with accelerated electrons (10 kGy, $100 \mathrm{kGy})$ under conditions of low pressure ( 0.01 Torr) and low temperature $\left(-130{ }^{\circ} \mathrm{C}\right)$, and also the viability of pure bacterial cultures under the same conditions. Radioresistance of a number of bacteria strains under normal conditions has also been evaluated. It is shown that irradiation with electrons with $100 \mathrm{kGy}$ dose in the model conditions of Mars and open space did not sterilize the samples of arid soils and permafrost. The data obtained suggest that viable microorganisms can be viably cryopreserved for at least 1.3 and 20 million years in the Mars regolith in the shallow surface layer and at $5 \mathrm{~m}$ depth, respectively; for at least $\sim 170$ years in the ice of Europa at $10 \mathrm{~cm}$ depth; for at least 400 thousand years in the open space inside the meteorites. 
We found that bacteria have a much higher radioresistance as a part of microbial communities in situ in the natural habitat when compared to their stability in pure culture. Due to the protective function of the natural environment and possibly due to the intra- and interpopulation interactions of organisms, even radiosensitive microorganisms being part of natural microbial communities are able to withstand the effects of high doses of ionizing radiation.

Author Contributions: V.C., E.V., and A.P. designed the study, all authors performed the study, V.C. and E.V. prepared draft manuscript, all authors edited and commented on the manuscript.

Funding: This research was funded by Russian Science Foundation grant number 17-12-01184, partially by the Program of the Presidium of the RAS "Evolution of the organic world and planetary processes" (1.22P, subprogramme 2; in part of pure bacterial cultures irradiation with accelerated electrons), and by the Act 211 Government of the Russian Federation, Agreement no. 02.A03.21.0006 (in part of pure bacterial cultures irradiation with gamma radiation). The APC was funded by Russian Science Foundation grant number 17-12-01184.

Acknowledgments: The authors express their respect for D.A. Gilichinsky, who provided samples of the Arctic permafrost, and also thank R. Angel and O.R. Kotsuyrbenko, who provided samples of the arid soil. The authors thank Solovyov V.Yu. for the help in irradiation with accelerated electrons and thank Vozhov A.V. and Khacheresyants G.V. for their help in carrying out irradiation with gamma radiation. The authors thank anonymous reviewers for the help in the improving of the article.

Conflicts of Interest: The authors declare no conflict of interest. The funders had no role in the design of the study; in the collection, analyses, or interpretation of data; in the writing of the manuscript, and in the decision to publish the results.

\section{Appendix A}

Table A1. The primers used for 16S rRNA gene amplification and sequencing.

\begin{tabular}{|c|c|c|}
\hline $\begin{array}{c}\text { Strain-GenBank Accession } \\
\text { Number }\end{array}$ & $\begin{array}{l}\text { Primers Used for the } \\
\text { Amplification }\end{array}$ & Primers Used for the Sequencing \\
\hline KBP.AS.531-MH050938 & $63 \mathrm{~F}+1387 \mathrm{R}$ & 1100R \\
\hline KBP.AS.532-MH050939 & $27 \mathrm{~F}+537 \mathrm{R}$ & $537 \mathrm{R}$ \\
\hline KBP.AS.340-MH050940 & $63 F+1387 R$ & $1100 \mathrm{R}$ \\
\hline KBP.AS.341-MH050941 & $63 \mathrm{~F}+1387 \mathrm{R}$ & $1100 \mathrm{R}$ \\
\hline KBP.AS.342-MH050942 & $63 F+1387 R$ & $1100 \mathrm{R}$ \\
\hline KBP.AS.343-MH050943 & $63 F+1387 R$ & $1100 \mathrm{R}$ \\
\hline KBP.AS.344-MH050944 & $63 \mathrm{~F}+1387 \mathrm{R}$ & 1100R \\
\hline KBP.AS.345-MH050945 & $63 F+1387 R$ & 1100R; 537R \\
\hline KBP.AS.346-MH050946 & $63 \mathrm{~F}+1387 \mathrm{R}$ & 1100R \\
\hline KBP.AS.347-MH050947 & $63 \mathrm{~F}+1387 \mathrm{R}$ & $1100 \mathrm{R}$ \\
\hline KBP.AS.298-MH050948 & $63 \mathrm{~F}+1387 \mathrm{R}$ & 1100R \\
\hline KBP.AS.299-MH050949 & $63 \mathrm{~F}+1387 \mathrm{R}$ & $1100 \mathrm{R}$ \\
\hline KBP.AS.300—MH050950 & $63 \mathrm{~F}+1387 \mathrm{R}$ & $1100 \mathrm{R}$ \\
\hline KBP.AS.533-MH050951 & $63 F+1387 R$ & 1100R \\
\hline KBP.AS.301-MH050952 & $63 \mathrm{~F}+1387 \mathrm{R}$ & $1100 \mathrm{R}$ \\
\hline KBP.AS.302-MH050953 & $63 F+1387 R$ & $1100 \mathrm{R}$ \\
\hline KBP.AS.303-MH050954 & $63 F+1387 R$ & $1100 \mathrm{R}$ \\
\hline KBP.AS.534-MH050955 & $27 \mathrm{~F}+\mathrm{Un} 1492 \mathrm{R}$ & $1100 \mathrm{R}$ \\
\hline KBP.AS.297-MH050956 & $63 \mathrm{~F}+1387 \mathrm{R}$ & 1100R \\
\hline KBP.AS.321—MH050957 & $63 \mathrm{~F}+1387 \mathrm{R}$ & 1100R; 537R \\
\hline KBP.AS.322-MH050958 & $63 F+1387 R$ & 1100R \\
\hline KBP.AS.323-MH050959 & $63 F+1387 R$ & $1100 \mathrm{R}$ \\
\hline KBP.AS.324-MH050960 & $63 \mathrm{~F}+1387 \mathrm{R}$ & $1100 \mathrm{R}$ \\
\hline KBP.AS.325-MH050961 & $63 F+1387 R$ & $1100 \mathrm{R}$ \\
\hline KBP.AS.535-MH050962 & $63 \mathrm{~F}+1387 \mathrm{R}$ & $1100 \mathrm{R}$ \\
\hline KBP.AS.536-MH050963 & $63 \mathrm{~F}+1387 \mathrm{R}$ & $1100 \mathrm{R}$ \\
\hline KBP.AS.326-MH050964 & $63 F+1387 R$ & 1100R; 537R \\
\hline KBP.AS.317-MH050965 & $63 F+1387 R$ & 1100R \\
\hline KBP.AS.319-MH050966 & $63 F+1387 R$ & 1100R \\
\hline KBP.AS.320-MH050967 & $63 F+1387 R$ & $1100 \mathrm{R}$ \\
\hline KBP.AS.537-MH050968 & $63 F+1387 R$ & $1100 R$ \\
\hline
\end{tabular}




\section{Appendix B}

Table A2. The bacterial genera cultured from the arid soil samples. The table summarizes some data of the Table 3 and allows to compare bacterial diversity in a simpler view.

\begin{tabular}{ccc}
\hline SN2, TPC & SN2, 10 kGy & SN2, 100 kGy \\
\hline Arthrobacter & Arthrobacter & Arthrobacter \\
Saccharothrix & & \\
Phenylobacterium & & \\
Cryobacterium & & \\
Streptomyces & & \\
Microbacterium & Micrococcus & \\
Micrococcus & & Spirosoma \\
Sphingoaurantiacus & Rufibacter \\
Bacillus & Spirosoma & \\
& Rufibacter & Microvirga \\
& Planomicrobium & Pontibacter \\
\hline
\end{tabular}

\section{References}

1. Cockell, C.S.; Schwendner, P.; Perras, A.; Rettberg, P.; Beblo-Vranesevic, K.; Bohmeier, M.; Rabbow, E.; Moissl-Eichinger, C.; Wink, L.; Marteinsson, V.; et al. Anaerobic microorganisms in astrobiological analogue environments: From field site to culture collection. Int. J. Astrobiol. 2017, 1-15. [CrossRef]

2. Horneck, G.; Walter, N.; Westall, F.; Grenfell, J.L.; Martin, W.F.; Gomez, F.; Leuko, S.; Lee, N.; Onofri, S.; Tsiganis, K.; et al. AstRoMap: European astrobiology roadmap. Astrobiology 2016, 16, 201-243. [CrossRef] [PubMed]

3. Domagal-Goldman, S.D.; Wright, K.E.; Adamala, K.; Arina de la Rubia, L.; Bond, J.; Dartnell, L.R.; Goldman, A.D.; Lynch, K.; Naud, M.-E.; Paulino-Lima, I.G.; et al. The astrobiology primer v2.0. Astrobiology 2016, 16, 561-653. [CrossRef] [PubMed]

4. Moeller, R.; Raguse, M.; Leuko, S.; Berger, T.; Hellweg, C.E.; Fujimori, A.; Okayasu, R.; Horneck, G. STARLIFE-An international campaign to study the role of galactic cosmic radiation in astrobiological model systems. Astrobiology 2017, 17, 101-109. [CrossRef] [PubMed]

5. Baumstark-Khan, C.; Facius, R. Life under conditions of ionizing radiation. In Astrobiology: The Quest for the Conditions of Life; Horneck, G., Baumstark-Khan, C., Eds.; Springer: Berlin, Germany, 2002; pp. 261-284. ISBN 978-3-642-59381-9. [CrossRef]

6. Cheptsov, V.S.; Vorobyova, E.A.; Manucharova, N.A.; Gorlenko, M.V.; Pavlov, A.K.; Vdovina, M.A.; Lomasov, V.N.; Bulat, S.A. 100 kGy gamma-affected microbial communities within the ancient Arctic permafrost under simulated Martian conditions. Extremophiles 2017, 21, 1057-1067. [CrossRef] [PubMed]

7. Cheptsov, V.S.; Vorobyova, E.A.; Gorlenko, M.V.; Manucharova, N.A.; Pavlov, A.K.; Lomasov, V.N. Effect of gamma radiation on viability of a soil microbial community under conditions of Mars. Paleontol. J. 2018, 52, 118-124. [CrossRef]

8. Vorobyova, E.A.; Cheptsov, V.S.; Osipov, G.A.; Kotsyurbenko, O.R.; Soina, V.S. Gamma-IR resistance of bacteria in soil and permafrost. Paleontol. J. 2018, in press.

9. Cheptsov, V.S.; Vorobyova, E.A.; Osipov, G.A.; Manucharova, N.A.; Polyanskaya, L.M.; Gorlenko, M.V.; Pavlov, A.K.; Rosanova, M.S.; Lomasov, V.N. Microbial activity in Martian analog soils after ionizing radiation: Implications for the preservation of subsurface life on Mars. AIMS Microbiol. 2018, 4, 541-562. [CrossRef]

10. Dartnell, L.R.; Hunter, S.J.; Lovell, K.V.; Coates, A.J.; Ward, J.M. Low-temperature ionizing radiation resistance of Deinococcus radiodurans and Antarctic Dry Valley bacteria. Astrobiology 2010, 10, 717-732. [CrossRef] [PubMed] 
11. Halliwell, B.; Gutteridge, J.M.C. Free Radicals in Biology and Medicine, 5th ed.; Oxford University Press: New York, NY, USA, 2015; p. 896. ISBN 9780198717485.

12. Gaziev, A.; Shaikhaev, G. Limited repair of critical DNA damage in cells exposed to low dose radiation. In Current Topics in Ionizing Radiation Research; Nenoi, M., Ed.; IntechOpen: London, UK, 2012; ISBN 978-953-51-0196-3. [CrossRef]

13. Benhamda, C.; Benkahla, A.; Miled, S.B.; Ouled-Haddar, H.; del Carmen Montero-Calasanz, M.; Gtari, M.; Cherif, A.; Hofner, B.; Ghedira, K.; Sghaier, H. The RadioP1-An integrative web resource for radioresistant prokaryotes. In Evolution of Ionizing Radiation Research; Nenoi, M., Ed.; InTechOpen: London, UK, 2015; pp. 89-106, ISBN 978-953-51-2167-1. [CrossRef]

14. Vorobyova, E.A.; Soina, V.S.; Mulukin, A.L. Microorganisms and enzyme activity in permafrost after removal of long-term cold stress. Adv. Space Res. 1996, 18, 103-108. [CrossRef]

15. Vorobyova, E.; Soina, V.; Gorlenko, M.; Minkovskaya, N.; Zalinova, N.; Mamukelashvili, A.; Gilichinsky, D.; Rivkina, E.; Vishnivetskaya, T. The deep cold biosphere: Facts and hypothesis. FEMS Microbiol. Rev. 1997, 20 , 277-290. [CrossRef]

16. Decho, A.W. Microbial biofilms in intertidal systems: An overview. Cont. Shelf Res. 2000, 20, 1257-1273. [CrossRef]

17. Frösler, J.; Panitz, C.; Wingender, J.; Flemming, H.C.; Rettberg, P. Survival of Deinococcus geothermalis in biofilms under desiccation and simulated space and Martian conditions. Astrobiology 2017, 17, 431-447. [CrossRef] [PubMed]

18. El-Registan, G.I.; Mulyukin, A.L.; Nikolaev, Y.A.; Suzina, N.E.; Gal'chenko, V.F.; Duda, V.I. Adaptogenic functions of extracellular autoregulators of microorganisms. Microbiology 2006, 75, 380-389. [CrossRef]

19. Pacelli, C.; Selbmann, L.; Zucconi, L.; Raguse, M.; Moeller, R.; Shuryak, I.; Onofri, S. Survival, DNA integrity, and ultrastructural damage in Antarctic cryptoendolithic eukaryotic microorganisms exposed to ionizing radiation. Astrobiology 2017, 17, 126-135. [CrossRef] [PubMed]

20. Dartnell, L.R.; Desorgher, L.; Ward, J.M.; Coates, A.J. Martian sub-surface ionising radiation: Biosignatures and geology. Biogeosci. Discuss. 2007, 4, 455-492. [CrossRef]

21. Dartnell, L.R.; Desorgher, L.; Ward, J.M.; Coates, A.J. Modelling the surface and subsurface Martian radiation environment: Implications for astrobiology. Geophys. Res. Lett. 2007, 34, L02207. [CrossRef]

22. Pavlov, A.A.; Vasilyev, G.; Ostryakov, V.M.; Pavlov, A.K.; Mahaffy, P. Degradation of the organic molecules in the shallow subsurface of Mars due to irradiation by cosmic rays. Geophys. Res. Lett. 2012, 39, L13202. [CrossRef]

23. Hassler, D.M.; Zeitlin, C.; Wimmer-Schweingruber, R.F.; Ehresmann, B.; Rafkin, S.; Eigenbrode, J.L.; Brinza, D.E.; Weigle, G.; Böttcher, S.; Böhm, E.; et al. Mars' surface radiation environment measured with the Mars Science Laboratory's Curiosity rover. Science 2014, 343, 1244797. [CrossRef] [PubMed]

24. Fairén, A.G.; Davila, A.F.; Lim, D.; Bramall, N.; Bonaccorsi, R.; Zavaleta, J.; Uceda, E.R.; Stoker, C.; Wierzchos, J.; Dohm, J.M.; et al. Astrobiology through the ages of Mars: The study of terrestrial analogues to understand the habitability of Mars. Astrobiology 2010, 10, 821-843. [CrossRef] [PubMed]

25. Westall, F.; Loizeau, D.; Foucher, F.; Bost, N.; Betrand, M.; Vago, J.; Kminek, G. Habitability on Mars from a microbial point of view. Astrobiology 2013, 13, 887-897. [CrossRef] [PubMed]

26. Ramirez, R.M.; Craddock, R.A. The geological and climatological case for a warmer and wetter early Mars. Nat. Geosci. 2018, 11, 230-237. [CrossRef]

27. Wordsworth, R.; Kalugina, Y.; Lokshtanov, S.; Vigasin, A.; Ehlmann, B.; Head, J.; Sanders, C.; Wang, H. Transient reducing greenhouse warming on early Mars. Geophys. Res. Lett. 2017, 44, 665-671. [CrossRef]

28. Wordsworth, R.D.; Kerber, L.; Pierrehumbert, R.T.; Forget, F.; Head, J.W. Comparison of "warm and wet" and "cold and icy" scenarios for early Mars in a 3-D climate model. J. Geophys. Res. Planets 2015, 120, 1201-1219. [CrossRef]

29. Ramirez, R.M. A warmer and wetter solution for early Mars and the challenges with transient warming. Icarus 2017, 297, 71-82. [CrossRef]

30. Kurokawa, H.; Kurosawa, K.; Usui, T. A lower limit of atmospheric pressure on early Mars inferred from nitrogen and argon isotopic compositions. Icarus 2018, 299, 443-459. [CrossRef]

31. Rivkina, E.M.; Kraev, G.N.; Krivushin, K.V.; Laurinavichus, K.S.; Fyodorov-Davydov, D.G.; Kholodov, A.L.; Shcherbakova, V.A.; Gilichinsky, D.A. Methane in permafrost of Northeastern Arctic. Earth Cryosphere 2006, 10, 23-41. (In Russian) 
32. Gilichinsky, D.A.; Vorobyova, E.A.; Erokhina, L.G.; Fyordorov-Dayvdov, D.G.; Chaikovskaya, N.R. Long-term preservation of microbial ecosystems in permafrost. Adv. Space Res. 1992, 12, 255-263. [CrossRef]

33. Cheptsov, V.S.; Vorobyova, E.A.; Polyanskaya, L.M.; Gorlenko, M.V.; Pavlov, A.K.; Lomasov, V.N. Sustainability of extreme microbial ecosystems to the complex impact of physical factors of Martian regolith. Moscow Univ. Soil Sci. Bull. 2018, 3, in press.

34. Angel, R.; Soares, M.I.M.; Ungar, E.D.; Gillor, O. Biogeography of soil archaea and bacteria along a steep precipitation gradient. ISME J. 2010, 4, 553. [CrossRef] [PubMed]

35. Singer, A. The Soils of Israel; Springer: Berlin, Germany, 2007; p. 306, ISBN 978-3-540-71734-8. [CrossRef]

36. Schumacher, B.A. Methods for the Determination of Total Organic Carbon (TOC) in Soils and Sediments; NCEA-C-1282; U.S. Environmental Protection Agency, National Exposure Research Laboratory: Washington, DC, USA, 2002; p. 23.

37. Cheptsov, V.S.; Vorobyova, E.A.; Gorlenko, M.V.; Manucharova, N.A.; Pavlov, A.K.; Vdovina, M.A.; Lomasov, V.N.; Zvyagintsev, D.G. Influence of gamma radiation, low pressure and low temperature on viability of microbial community of the gray soil as analytical model of Martian regolith. Sovr. Probl. Nauki Obrazov. 2015, 3. Available online: https://science-education.ru/pdf/2015/3/515.pdf (accessed on 10 August 2017). (In Russian)

38. Cheptsov, V.S.; Vorobyova, E.A.; Tambiev, A.H.; Pavlov, A.K.; Vdovina, M.A.; Lomasov, V.N.; Zvyagintsev, D.G. Influence of gamma radiation, low pressure and low temperature on catalase activity and reactivity of exometabolites of Kocuria rosea and Arthrobacter polychromogenes. Sovr. Probl. Nauki Obrazov. 2016, 5. Available online: https:/ / science-education.ru/pdf/2016/5/25133.pdf (accessed on 12 June 2018). (In Russian)

39. Cheptsov, V.S.; Vorobyova, E.A.; Tambiev, A.H.; Pavlov, A.K.; Vdovina, M.A.; Lomasov, V.N. Influence of gamma irradiation in simulated Martian conditions on catalase activity and reactivity of exometabolites of Kocuria rosea and Arthrobacter polychromogenes. In The Seventh Moscow Solar System Symposium (7M-S3); Russian Academy of Sciences: Moscow, Russia, 2016; pp. 262-264, ISBN 978-5-00015-013-9. Available online: http:/ / ms2016.cosmos.ru/sites/ms2016.cosmos.ru/files/7ms3-2016_abstract_book_www.pdf (accessed on 20 June 2018).

40. Gorlenko, M.V.; Majorova, T.N.; Kozhevin, P.A. Disturbances and their influence on substrate utilization patterns in soil microbial communities. In Microbial Communities; Insam, H., Rangger, A., Eds.; Springer: Berlin, Germany, 1997; pp. 84-93, ISBN 978-3-642-60694-6. [CrossRef]

41. Gorlenko, M.V.; Kozhevin, P.A. Differentiation of soil microbial communities by multisubstrate testing. Microbiology 1994, 63, 158-161.

42. Garland, J.L.; Mills, A.L. A community-level physiological approach for studying microbial communities. In Beyond the Biomass: Compositional and Functional Analysis of Soil Microbial Communities; Ritz, K., Dighton, J., Giller, K.E., Eds.; Wiley: Chichester, UK, 1994; pp. 77-83, ISBN 978-0471950967.

43. Garland, J.L.; Mills, A.L. Classification and characterization of heterotrophic microbial communities on the basis of patterns of community-level sole-carbon-source utilization. Appl. Environ. Microbiol. 1991, 57, 2351-2359. [PubMed]

44. Atlas, R.M. Handbook of Microbiological Media, 4th ed.; CRC Press: Boca Raton, FL, USA, 2010; p. 2036, ISBN 9781439804087.

45. Gorlenko, M.V.; Kozhevin, P.A. Multisubstrate Testing of Natural Microbial Communities; MAKS Press: Moscow, Russia, 2005; p. 88, ISBN 5-317-01228-7. (In Russian)

46. Manaeva, E.S.; Lomovtseva, N.O.; Kostina, N.V.; Gorlenko, M.V.; Umarov, M.M. Biological activity of soils in the settlements of southern (Microtus rossiaemeridionalis) and bank (Clethrionomys glareolus) voles. Biol. Bull. 2014, 41, 80-88. [CrossRef]

47. Marchesi, J.R.; Sato, T.; Weightman, A.J.; Martin, T.A.; Fry, J.C.; Hiom, S.J.; Wade, W.G. Design and evaluation of useful bacterium-specific PCR primers that amplify genes coding for bacterial 16S rRNA. Appl. Environ. Microbiol. 1998, 64, 795-799. [PubMed]

48. Weisburg, W.G.; Barns, S.M.; Pelletier, D.A.; Lane, D.J. 16S ribosomal DNA amplification for phylogenetic study. J. Bacteriol. 1991, 173, 697-703. [CrossRef] [PubMed]

49. DeLong, E.F. Archaea in coastal marine environments. Proc. Natl. Acad. Sci. USA 1992, 89, 5685-5689. [CrossRef] [PubMed] 
50. Lane, D.J. 16S/23S rRNA sequencing. In Nucleic Acid Techniques in Bacterial Systematic; Stackebrandt, E., Goodfellow, M., Eds.; John Wiley \& Sons Ltd.: West Sussex, UK, 1991; pp. 115-175, ISBN 9780471929062.

51. Gerhardt, F. Methods of General Bacteriology; Mir: Moscow, Russia, 1983; p. 536. (In Russian)

52. Cox, M.M.; Battista, J.R. Deinococcus radiodurans-The consummate survivor. Nat. Rev. Microbiol. 2005, 3, 882-892. [CrossRef] [PubMed]

53. Musilova, M.; Wright, G.; Ward, J.M.; Dartnell, L.R. Isolation of radiation-resistant bacteria from Mars analog Antarctic Dry Valleys by preselection, and the correlation between radiation and desiccation resistance. Astrobiology 2015, 15, 1076-1090. [CrossRef] [PubMed]

54. Verseux, C.; Baqué, M.; Cifariello, R.; Fagliarone, C.; Raguse, M.; Moeller, R.; Billi, D. Evaluation of the resistance of Chroococcidiopsis spp. to sparsely and densely ionizing irradiation. Astrobiology 2017, 17, 118-125. [CrossRef] [PubMed]

55. Bauermeister, A.; Moeller, R.; Reitz, G.; Sommer, S.; Rettberg, P. Effect of relative humidity on Deinococcus radiodurans' resistance to prolonged desiccation, heat, ionizing, germicidal, and environmentally relevant UV radiation. Microb. Ecol. 2011, 61, 715-722. [CrossRef] [PubMed]

56. Gilichinsky, D. Permafrost as a microbial habitat. In Encyclopedia of Environmental Microbiology; Bitton, G., Ed.; Wiley: New York, NY, USA, 2002; pp. 932-956, ISBN 978-0-471-35450-5.

57. Harris, D.R.; Pollock, S.V.; Wood, E.A.; Goiffon, R.J.; Klingele, A.J.; Cabot, E.L.; Schackwitz, W.; Martin, J.; Eggington, J.; Durfee, T.J.; et al. Directed evolution of ionizing radiation resistance in Escherichia coli. J. Bacteriol. 2009, 191, 5240-5252. [CrossRef] [PubMed]

58. Tesfai, A.T.; Beamer, S.K.; Matak, K.E.; Jaczynski, J. Radio-resistance development of DNA repair deficient Escherichia coli DH5 $\alpha$ in ground beef subjected to electron beam at sub-lethal doses. Int. J. Radiat. Biol. 2011, 87, 571-578. [CrossRef] [PubMed]

59. Soina, V.S.; Mulyukin, A.L.; Demkina, E.V.; Vorobyova, E.A.; El-Registan, G.I. The structure of resting bacterial populations in soil and subsoil permafrost. Astrobiology 2004, 4, 345-358. [CrossRef] [PubMed]

60. Goordial, J.; Davila, A.; Greer, C.W.; Cannam, R.; DiRuggiero, J.; McKay, C.P.; Whyte, L.G. Comparative activity and functional ecology of permafrost soils and lithic niches in a hyper-arid polar desert. Environ. Microbiol. 2017, 19, 443-458. [CrossRef] [PubMed]

61. Singh, P.; Singh, S.M.; Dhakephalkar, P. Diversity, cold active enzymes and adaptation strategies of bacteria inhabiting glacier cryoconite holes of High Arctic. Extremophiles 2014, 18, 229-242. [CrossRef] [PubMed]

62. Bajerski, F.; Ganzert, L.; Mangelsdorf, K.; Lipski, A.; Wagner, D. Cryobacterium arcticum sp. nov., a psychrotolerant bacterium from an Arctic soil. Int. J. Syst. Evol. Microbiol. 2011, 61, 1849-1853. [CrossRef] [PubMed]

63. Shivaji, S.; Kumari, K.; Kishore, K.H.; Pindi, P.K.; Rao, P.S.; Srinivas, T.N.R.; Asthana, R.; Ravindra, R. Vertical distribution of bacteria in a lake sediment from Antarctica by culture-independent and culture-dependent approaches. Res. Microbiol. 2011, 162, 191-203. [CrossRef] [PubMed]

64. Yu, L.Z.H.; Luo, X.S.; Liu, M.; Huang, Q. Diversity of ionizing radiation-resistant bacteria obtained from the Taklimakan Desert. J. Basic Microbiol. 2015, 55, 135-140. [CrossRef] [PubMed]

65. Osman, S.; Peeters, Z.; La Duc, M.T.; Mancinelli, R.; Ehrenfreund, P.; Venkateswaran, K. Effect of shadowing on survival of bacteria under conditions simulating the Martian atmosphere and UV radiation. Appl. Environ. Microbiol. 2008, 74, 959-970. [CrossRef] [PubMed]

66. Lee, J.J.; Srinivasan, S.; Lim, S.; Joe, M.; Im, S.; Bae, S.I.; Park, S.J.; Han, J.-H.; Park, S.-H.; Joo, B.-M.; et al. Spirosoma radiotolerans sp. nov., a gamma-radiation-resistant bacterium isolated from gamma ray-irradiated soil. Curr. Microbiol. 2014, 69, 286-291. [CrossRef] [PubMed]

67. Deng, W.; Yang, Y.; Gao, P.; Chen, H.; Wen, W.; Sun, Q. Radiation-resistant Micrococcus luteus sc1204 and its proteomics change upon gamma irradiation. Curr. Microbiol. 2016, 72, 767-775. [CrossRef] [PubMed]

68. Rao, S.; Chan, O.W.; Lacap-Bugler, D.C.; Pointing, S.B. Radiation-tolerant bacteria isolated from high altitude soil in Tibet. Indian J. Microbiol. 2016, 56, 508-512. [CrossRef] [PubMed]

69. Ishii, N.; Fuma, S.; Tagami, K.; Honma-Takeda, S.; Shikano, S. Responses of the bacterial community to chronic gamma radiation in a rice paddy ecosystem. Int. J. Radiat. Biol. 2011, 87, 663-672. [CrossRef] [PubMed]

70. Verde, S.C.; Silva, T.; Matos, P. Effects of gamma radiation on wastewater microbiota. Radiat. Environ. Biophys. 2016, 55, 125-131. [CrossRef] [PubMed] 
71. Williams, P.D.; Eichstadt, S.L.; Kokjohn, T.A.; Martin, E.L. Effects of ultraviolet radiation on the gram-positive marine bacterium Microbacterium maritypicum. Curr. Microbiol. 2007, 55, 1-7. [CrossRef] [PubMed]

72. Etemadifar, Z.; Gholami, M.; Derikvand, P. UV-resistant bacteria with multiple-stress tolerance isolated from desert areas in Iran. Geomicrobiol. J. 2016, 33, 1-7. [CrossRef]

73. Zamanian, S.N.; Etemadifar, Z. Radical scavengering of pigments from novel strains of Dietzia schimae and Microbacterium esteraromaticum. Prog. Biol. Sci. 2017, 6, 159-170. [CrossRef]

74. Chattopadhyay, M.K.; Raghu, G.; Sharma, Y.V.R.K.; Biju, A.R.; Rajasekharan, M.V.; Shivaji, S. Increase in oxidative stress at low temperature in an Antarctic bacterium. Curr. Microbiol. 2011, 62, 544-546. [CrossRef] [PubMed]

75. Torsvik, V.; Øvreås, L. Microbial diversity, life strategies, and adaptation to life in extreme soils. In Microbiology of Extreme Soils; Dion, P., Nautiyal, C.S., Eds.; Springer: Berlin, Germany, 2008; pp. 15-43, ISBN 978-3-540-74231-9.

76. Stotzky, G. Influence of soil mineral colloids on metabolic processes, growth, adhesion, and ecology of microbes and viruses 1 . Interactions of soil minerals with natural organics and microbes. In Interactions of Soil Minerals with Natural Organics and Microbes; Huang, P.M., Schnitzer, M., Eds.; Soil Science Society of America: Madison, WI, USA, 1986; pp. 305-428, ISBN 978-0-89118-912-1.

77. Hattori, T.; Hattori, R.; McLaren, A.D. The physical environment in soil microbiology: An attempt to extend principles of microbiology to soil microorganisms. CRC Crit. Rev. Microbiol. 1976, 4, 423-461. [CrossRef] [PubMed]

78. Dieser, M.; Greenwood, M.; Foreman, C.M. Carotenoid pigmentation in Antarctic heterotrophic bacteria as a strategy to withstand environmental stresses. Arct. Antarct. Alp. Res. 2010, 42, 396-405. [CrossRef]

79. Jacobs, J.L.; Carroll, T.L.; Sundin, G.W. The role of pigmentation, ultraviolet radiation tolerance, and leaf colonization strategies in the epiphytic survival of phyllosphere bacteria. Microb. Ecol. 2005, 49, 104-113. [CrossRef] [PubMed]

80. Pacelli, C.; Bryan, R.A.; Onofri, S.; Selbmann, L.; Zucconi, L.; Shuryak, I.; Dadachova, E. The effect of protracted X-ray exposure on cell survival and metabolic activity of fast and slow growing fungi capable of melanogenesis. Environ. Microbiol. Rep. 2018, 10, 255-263. [CrossRef] [PubMed]

81. El-Registan, G.I.; Mulyukin, A.L.; Nikolaev, Y.A.; Stepanenko, I.Y.; Kozlova, A.N.; Martirosova, E.I.; Shanenko, E.F.; Strakhovskaya, M.G.; Revina, A.A. The role of microbial low-molecular-weight autoregulatory factors (alkylhydroxybenzenes) in resistance of microorganisms to radiation and heat shock. Adv. Space Res. 2005, 36, 1718-1728. [CrossRef]

82. McNamara, N.P.; Black, H.I.J.; Beresford, N.A.; Parekh, N.R. Effects of acute gamma irradiation on chemical, physical and biological properties of soils. Appl. Soil Ecol. 2003, 24, 117-132. [CrossRef]

83. García-Contreras, R.; Nunez-Lopez, L.; Jasso-Chávez, R.; Kwan, B.W.; Belmont, J.A.; Rangel-Vega, A.; Maeda, T.; Wood, T.K. Quorum sensing enhancement of the stress response promotes resistance to quorum quenching and prevents social cheating. ISME J. 2015, 9, 115-125. [CrossRef] [PubMed]

84. Chanal, A.; Chapon, V.; Benzerara, K.; Barakat, M.; Christen, R.; Achouak, W.; Barras, F.; Heulin, T. The desert of Tataouine: an extreme environment that hosts a wide diversity of microorganisms and radiotolerant bacteria. Environ. Microbiol. 2006, 8, 514-525. [CrossRef] [PubMed]

85. Rainey, F.A.; Ray, K.; Ferreira, M.; Gatz, B.Z.; Nobre, M.F.; Bagaley, D.; Rash, B.A.; Park, M.-J.; Earl, A.M.; Shank, N.C.; et al. Extensive diversity of ionizing-radiation-resistant bacteria recovered from Sonoran Desert soil and description of nine new species of the genus Deinococcus obtained from a single soil sample. Appl. Environ. Microbiol. 2005, 71, 5225-5235. [CrossRef] [PubMed]

86. Mileikowsky, C.; Cucinotta, F.A.; Wilson, J.W.; Gladman, B.; Horneck, G.; Lindegren, L.; Melosh, J.; Rickman, H.; Valtonen, M.; Zheng, J.Q. Natural transfer of viable microbes in space: 1. From Mars to Earth and Earth to Mars. Icarus 2000, 145, 391-427. [CrossRef] [PubMed]

87. Homeck, G.; Mileikowsky, C.; Melosh, H.J.; Wilson, J.W.; Cucinotta, F.A.; Gladman, B. Viable transfer of microorganisms in the solar system and beyond. In Astrobiology: The Quest for the Conditions of Life; Horneck, G., Baumstark-Khan, C., Eds.; Springer: Berlin, Germany, 2002; pp. 57-76, ISBN 978-3-642-59381-9. [CrossRef]

88. Rummel, J.D.; Beaty, D.W.; Jones, M.A.; Bakermans, C.; Barlow, N.G.; Boston, P.J.; Chevrier, V.F.; Clark, B.C.; de Vera, J.-P.P.; Gough, R.V.; et al. A new analysis of Mars "special regions": Findings of the second MEPAG Special Regions Science Analysis Group (SR-SAG2). Astrobiology 2014, 14, 887-968. [CrossRef] [PubMed] 
89. Dieser, M.; Battista, J.R.; Christner, B.C. Double-strand DNA break repair at $-15^{\circ} \mathrm{C}$. Appl. Environ. Microbiol. 2013, 79, 7662-7668. [CrossRef] [PubMed]

90. Pavlov, A.K.; Shelegedin, V.N.; Vdovina, M.A.; Pavlov, A.A. Growth of microorganisms in Martian-like shallow subsurface conditions: laboratory modelling. Int. J. Astrobiol. 2010, 9, 51-58. [CrossRef]

91. Martín-Torres, F.J.; Zorzano, M.P.; Valentín-Serrano, P.; Harri, A.M.; Genzer, M.; Kemppinen, O.; Rivera-Valentin, E.G.; Jun, I.; Wray, J.J.; Madsen, M.B.; et al. Transient liquid water and water activity at Gale crater on Mars. Nat. Geosci. 2015, 8, 357-361. [CrossRef]

92. Jones, E.G. Shallow transient liquid water environments on present-day Mars, and their implications for life. Acta Astronaut. 2018, 146, 144-150. [CrossRef]

93. Jones, E.G.; Lineweaver, C.H.; Clarke, J.D. An extensive phase space for the potential Martian biosphere. Astrobiology 2011, 11, 1017-1033. [CrossRef] [PubMed]

94. Nicholson, W.L.; Krivushin, K.; Gilichinsky, D.; Schuerger, A.C. Growth of Carnobacterium spp. from permafrost under low pressure, temperature, and anoxic atmosphere has implications for Earth microbes on Mars. Proc. Nat. Acad. Sci. USA 2013, 110, 666-671. [CrossRef] [PubMed]

95. Nicholson, W.L.; McCoy, L.E.; Kerney, K.R.; Ming, D.W.; Golden, D.C.; Schuerger, A.C. Aqueous extracts of a Mars analogue regolith that mimics the Phoenix landing site do not inhibit spore germination or growth of model spacecraft contaminants Bacillus subtilis 168 and Bacillus pumilus SAFR-032. Icarus 2012, 220, 904-910. [CrossRef]

96. Beblo-Vranesevic, K.; Huber, H.; Rettberg, P. High tolerance of Hydrogenothermus marinus to sodium perchlorate. Front. Microbiol. 2017, 8, 1369. [CrossRef] [PubMed]

97. Beblo-Vranesevic, K.; Bohmeier, M.; Perras, A.K.; Schwendner, P.; Rabbow, E.; Moissl-Eichinger, C.; Cockell, C.S.; Pukall, R.; Vannier, P.; Marteinsson, V.T.; et al. The responses of an anaerobic microorganism, Yersinia intermedia MASE-LG-1 to individual and combined simulated Martian stresses. PLoS ONE 2017, 12, e0185178. [CrossRef] [PubMed]

98. Al Soudi, A.F.; Farhat, O.; Chen, F.; Clark, B.C.; Schneegurt, M.A. Bacterial growth tolerance to concentrations of chlorate and perchlorate salts relevant to Mars. Int. J. Astrobiol. 2017, 16, 229-235. [CrossRef]

99. Nuding, D.L.; Gough, R.V.; Venkateswaran, K.J.; Spry, J.A.; Tolbert, M.A. Laboratory investigations on the survival of Bacillus subtilis spores in deliquescent salt Mars analog environments. Astrobiology 2017, 17, 997-1008. [CrossRef] [PubMed]

100. Heinz, J.; Schirmack, J.; Airo, A.; Kounaves, S.P.; Schulze-Makuch, D. Enhanced microbial survivability in subzero brines. Astrobiology 2018, 18, 1-10. [CrossRef] [PubMed]

101. Murray, J.B.; Muller, J.P.; Neukum, G.; Werner, S.C.; van Gasselt, S.; Hauber, E.; Markiewicz, W.J.; Head, J.W., III; Foing, B.H.; Page, D.; et al. The HRSC Co-Investigator Team. Evidence from the Mars Express High Resolution Stereo Camera for a frozen sea close to Mars' equator. Nature 2005, 434, 352-356. [CrossRef] [PubMed]

102. Mustard, J.F.; Cooper, C.D.; Rifkin, M.K. Evidence for recent climate change on Mars from the identification of youthful near-surface ground ice. Nature 2001, 412, 411-414. [CrossRef] [PubMed]

103. Madeleine, J.B.; Head, J.W.; Forget, F.; Navarro, T.; Millour, E.; Spiga, A.; Colaïtis, A.; Määttänen, A.; Montmessin, F.; Dickson, J.L. Recent ice ages on Mars: The role of radiatively active clouds and cloud microphysics. Geophys. Res. Lett. 2014, 41, 4873-4879. [CrossRef]

104. Johnsson, A.; Reiss, D.; Hauber, E.; Hiesinger, H.; Zanetti, M. Evidence for very recent melt-water and debris flow activity in gullies in a young mid-latitude crater on Mars. Icarus 2014, 235, 37-54. [CrossRef]

105. Hahn, C.; Hans, M.; Hein, C.; Mancinelli, R.L.; Mücklich, F.; Wirth, R.; Rettberg, P.; Hellweg, C.E.; Moeller, R. Pure and oxidized copper materials as potential antimicrobial surfaces for spaceflight activities. Astrobiology 2017, 17, 1183-1191. [CrossRef] [PubMed]

106. Koskinen, K.; Rettberg, P.; Pukall, R.; Auerbach, A.; Wink, L.; Barczyk, S.; Perras, A.; Mahnert, A.; Margheritis, D.; Kminek, G.; et al. Microbial biodiversity assessment of the European Space Agency's ExoMars 2016 mission. Microbiome 2017, 5, 143. [CrossRef] [PubMed]

107. Thomas, H.; Rettberg, P.; Shimizu, T.; Thoma, M. Cold atmospheric plasma technology for decontamination of space equipment. In Proceedings of the 6th International Conference on Plasma Medicine, Bratislava, Slovakia, 4-9 September 2016.

108. Dartnell, L.R. Ionizing radiation and life. Astrobiology 2011, 11, 551-582. [CrossRef] [PubMed] 
109. Noffke, N.; Christian, D.; Wacey, D.; Hazen, R.M. Microbially induced sedimentary structures recording an ancient ecosystem in the ca. 3.48 billion-year-old dresser formation, Pilbara, Western Australia. Astrobiology 2013, 13, 1-22. [CrossRef] [PubMed]

110. Grosch, E.G.; McLoughlin, N. Reassessing the biogenicity of Earth's oldest trace fossil with implications for biosignatures in the search for early life. Proc. Natl. Acad. Sci. USA 2014, 111, 8380-8387. [CrossRef] [PubMed]

111. Nutman, A.P.; Bennett, V.C.; Friend, C.R.; Van Kranendonk, M.J.; Chivas, A.R. Rapid emergence of life shown by discovery of 3,700-million-year-old microbial structures. Nature 2016, 537, 535-538. [CrossRef] [PubMed]

112. Allwood, A.C. Geology: Evidence of life in Earth's oldest rocks. Nature 2016, 537, 500-501. [CrossRef] [PubMed]

113. Giardino, G.; Pillitteri, I.; Favata, F.; Micela, G. The X-ray luminosity of solar-mass stars in the intermediate age open cluster NGC 752. Astron. Astrophys. 2008, 490, 113-123. [CrossRef]

114. Ribas, I.; Guinan, E.F.; Güdel, M.; Audard, M. Evolution of the solar activity over time and effects on planetary atmospheres. I. High-energy irradiances (1-1700 Å). Astrophys. J. 2005, 622, 680-694. [CrossRef]

115. Cnossen, I.; Sanz-Forcada, J.; Favata, F.; Witasse, O.; Zegers, T.; Arnold, N.F. Habitat of early life: Solar X-ray and UV radiation at Earth's surface 4-3.5 billion years ago. JGR: Planets 2007, 112, E02008. [CrossRef]

116. Kasting, J.F. Atmospheric composition of Hadean-early Archean Earth: The importance of CO. In Earth's Early Atmosphere and Surface Environment; Shaw, G.H., Ed.; Geological Society of America: Boulder, CO, USA, 2014; pp. 19-28, ISBN 9780813725048. [CrossRef]

117. Karam, P.A.; Leslie, S.A. Calculations of background beta-gamma radiation dose through geologic time. Health Phys. 1999, 77, 662-667. [CrossRef] [PubMed]

118. Pavlov, A.K.; Kalinin, V.L.; Konstantinov, A.N.; Shelegedin, V.N.; Pavlov, A.A. Was Earth ever infected by martian biota? Clues from radioresistant bacteria. Astrobiology 2006, 6, 911-918. [CrossRef] [PubMed]

119. Obridko, V.N.; Miroshnichenko, L.I.; Ragulskaya, M.V.; Khabarova, O.V.; Khramova, E.G.; Katsova, M.M.; Livshits, M.A. Space factor of the biosphere evolution: new fields of investigation. In Problems of Evolution of the Biosphere; Rozhnov, S.V., Ed.; PIN RAS: Moscow, Russia, 2013; pp. 66-94, ISBN 978-5-903825-31-8. (In Russian)

120. Obridko, V.N.; Ragulskaya, M.V.; Khabarova, O.V.; Miroshnichenko, L.I.; Khramova, E.G. Cosmophysical factors of evolution of biosphere: new lines of research. Psychosom. Integr. Res. 2015, 1, 0101. (In Russian) 